筆者は本セッションの年次的傾向推移についての知 識をもたず，従ってその紹介も論評もできないことを お詫びする.

本セッションでは, 演題 110 が発表取消となり 4 題 の発表で,討論時間は十分となったが, 参集者はきわめ て少数で, 活発な発言にもかかわらず,一同の諒解のも とに約 30 分の時間をあました. また 4 題とも相互に領 域も論旨も独立で, 発表者相互の討論は成立しょうが なかったのでまとまった盛り上りは扣こらなかった。 筆者の司会の不手際もあったであろらが，プログラム 偏成の影響もあったと思われる.

108 教育的構えについて

演者堀は臨床事例を1つの素材として, 教育的構え について「教える構え」を否定して「育てる構え」で なければならないことを提唱した。 その中で，かつて 本学会で招待講演をされた鈴木鎮一氏にふれた事に対 して黒田正典より発言があり, 演者は鈴木氏は「育て る構え」に徹したすぐれた教育実践者であると再度強 調し, しかしバイオリン教室における親には, その構 えがもてず教える構えとなるために，その子が，音楽 はすきだがレッスンはきらい，といらようになる場合 が少なくないことを答えた。

109 集合論の心理学研究への適用について (II)

演者江川は, 日心大会における発表の展開として, 任意の 2 つの存在物間の共通点と差異点とを見出すと いら認識行為に集合論を適用することを論じた。演者 もいらよらに, おそらくそれと気がつかずに心理学研
究においても集合論的思考を適用している場合がある であろらが，方法論としてこれを自覚的に適用する方 法の提唱として注目される.これに対して黒田正典か ら，具体的に実例で集合論の適用を示してほしいとの 要望が出された。

\section{1 教育心理学々授業研究}

演者奥野は，本学会の動向を，欧米における教育心 理学会の発表演題分類とも対比して鋭く批判し, 本来 の教育心理学とは何ぞやといらことを問らた上での研 究発表であってしかるべきで, 一般心理学の課題研究 発表の方が多くて, 授業研究が少なすぎると怒りをこ めて指摘された。これに対して望月享子は，その主旨 に共鳴を示し、いくつかの主題を具体的に示しながら 教育心理学はもっと実用的な面に関与すべきであろう と強調した。

\section{2 人間形成の方法的課題}

演者花岡は, 戦前に比して幸せなはずの現在の青少 年のもつ問題太現在の教育の查みとの対比において分 析し, 人間形成の教育的方法として, 5 個の観点の総合

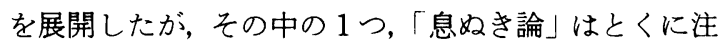
目されて,たとえば奥野明は, それは心理学理論なのか 単なる観念なのかの質問があり，演者は実践として回 答あり, 黒田正典は, 実際の指導に使っておられるか との質問に対して演者は教育実践者であることを答え た.

（堀 要 - 奥野 明）

\title{
発 達（201～208）
}

座長 藤嶋輝子・森 敏昭

201 幼児の自由再生に及ぼす訓練の効果

東京成徳短期大学 藤 嶋 輝子

202 自由再生に及ぽす分類条件の比較

奈良教育大学 藤 田正

203 幼児の対連合学習における身体活動の効果

広島大学田中昭夫

204 日本語一字音節の類似度測定と対連合学習

筑波大学 守 一 雄

205 子どもに於ける記憶の体制について（I)

愛知教育大学 多 鹿 秀 継

206 幼児における記憶の体制化過程の分析 (7)

207

比治山女子短期大学 (7)宮 崎 正 明
広島大学 (8)加 来 秀 俊 208 幼児における記憶の体制化過程の分析 (9)

\section{広島大学 (9)森 敏 昭}

この部会では, 記憶の体制化に関する研究 $(201,202$, $205,207,208$ ), 幼児の対連合学習に関する研究 (203), 日本語一字音節の類似度測定に関する研究 (204) の発 表が行われた.このように,この部会では記憶の体制 化の問題が主要なテーマであった. 昨年の 17 回総会と 比較しても, この問題に関する研究は全体的に増加し ており，質的にも進展のあとがうかがえる．昨年まで は, 体制化の程度が年齢とともにどのように変化する かを, 種々の実験条件下で調べようという，いわば探 
索的研究が多かったが, 今回の大会では, 一歩すすめ て, 体制化の発達機序の解明をめざすものが多くなっ てきた点を一応の成果とみることができよう。

大会初日の午前中ということもあってか, 出席者の 数は少なかったものの, 以下に述べるような, 白熱し た討論が展開された。

201 番の藤島は, 5 才児を被験者とし, カードをカテ ゴリーごとに分類する練習をあらかじめ行う分類群, 記録用のカードを提示した後, 同じカテゴリーに属す る語をまとめさせるブロック群, 及び統制群の群化量 と再生数を比較したデータを報告した。 この報告に対 しては「3 群は練習の条件, 記銘時の条件, 再生時の条 件がいずれる違っているので，どうして結果に差が生 じたのかわからないのではないのか」(福教大, 森),

「分類群には, 練習時においても本課題に怙いても力 テゴリーについての教示が与えられるので, 練習の効 果をみることはできないのではないか」(多鹿・愛知教 育大）といら問題点が指摘された。 また,「分類群では, 再生カテゴリ一数が増加し, ブロック群ではカテゴ リ一当りの再生項目数が増加しているのはどうして か」といら質問があり（森・福教大）「明確ではない が，子どもには大人とちがう体制化のしくみがあるの ではないか」という答えがなされた。

201 番の藤田は, 成人の分類基準にしたがって分類 作業させる条件と子どもの基準にしたがって自由に分 類させる条件との比較を行い, 両条件に顕著な差がな いといら結果を報告した.この報告に対しては,「もう 少し年齢を下げれば条件差が出たのではないか」とい ら指摘がなされ（宮崎・比治山女子短大）藤田もこの 意見に同意した。

203 番の田中は, 対連合学習を行う際に, 手で玩具を 操作することの効果を調べた実験結果を報告した。こ の報告に対しては,「各条件で Motivation の違いはな かったか」といら質問がなされ，森（前出）, 特にその ような感じは受けなかったといら答えがなされた。ま た、「具体的にはどのような関係づけがなされたのか」 という質問に対して, 森 (前出) Rohwen 等の分類に 従えば動詞的結合といらカテゴリーに入るものが多 かったが，このような関係づけが, Imagery的なもの か, Verbal なものかは明確でないと答えた。

204 番の守は, 日本語一字音節の類似度を SD 法を 用いて測定し, 単純さと美しさという2つの次元があ るといら報告を行った.この報告に対して,「評定に用 いた形容詞対は，どのようにして選択したのか」とい 万質問がなされ, 宮崎 (.前出) Osgood の見出した $3 つ$ の次元を代表する形容詞対を用いたという答弁がなさ
れた.「ここで測定された印象の次元と, 有意味度や連 想価とはどらいう関係があるか」といら質問に対し， 森（前出）相関をとっていないので，はっきりしたこ とはいえないが，特に関係はないようだと答えた。 は た,「一字音節の中には有意味なものと無意味なものと があるので, 文字もしくは音節に対する印象と, 意味 に対する印象とが，区別しにくいのではないかという 質問があったが, 森 (前出), 教示で文字もしくは音節 に対する印象を評定するよらに強調したので特に問題 はないだろらと答えた。

205 番の多鹿は, 部分りストから全体リストへの転 移パラダイムを用いて, 文章化教示の効果を検討した. この報告に対して，文章を作るには時間が少なすぎた のではないかという指摘がなされ（藤島・東京成徳短 期大学), 多鹿も同意した. 項目間の連想関係が影響す るのではないかという質問に対し(荒木・宮崎大学), 特に問題はなかったように思らという答えがなされ た. また，文章化教示の効果が実験群と統制群で違い があるようだが，それはどうしてだと考えられるかと いら質問に対し, 森 (前出), 何らかの Inhibition が働 いたものと考えられるが，これだけのデータでははっ きりしたことは言えないと答えた。

206 番から 208 番までは, 宮崎, 森, 加来による一連 の共同研究のデータが報告された. 206 番の研究では 体制化の発達と概念分類能力との関係が分析された. 次に 207 番の研究では, 低年齢の幼児が年長児ほど群 化を示さないものは, 記銘時に概念を利用できないこ とによるのか，検索時に利用できないことによるのか という問題が検討された. 208 番の研究では, 記銘時に 概念を利用した場合と利用しなかった場合とで検索手 がかりを与えることの効果に差が生じるかどうかが検 討された. 206 番の研究に対し,「概念の発達とはどの ようなことを考えているのか」という質問がなされ(藤 島・東京成徳短期大学), この研究では, 概念能力の中 でも，事例をカテゴリーごとに分類する能力を問題に したといら答えがなされた. 207 番の研究に対して,

「低頻度語を記銘材料として用いた方がよかったので はないか」といら意見が出されたが (野村・関学), 低 頻度語を用いれば，手がかりを与えることの効果が十 分あらわれない危険性があったので高頻度語を用いた といら答えがなされた. 208 番の研究に対して,「色と 概念的カテゴリーでは, 次元の Salience が違らのでは ないか」という指摘がなされたが (野村・前出), 確か にそのとらりだが，この研究の目的には，その点はさ ほど問題にならないという答えがなされた。

（森 敏昭） 


\section{発 達 (209 216)}

座長久保田 正 人・三浦 香 苗

$209\lceil い く つ$ 多いか」の判断の獲得（続報として）

宮城教育大学 久保田 正人

210 クラス包摂の条件として “すべでと "いくら" かの問題

$\begin{array}{crrrr}\text { 香川大学 } & \text { ○中 } & \text { 塚 } & \text { 勝 } & \text { 俊 } \\ \prime \prime & \text { 高 } & \text { 橋 } & \text { 茂 } & \text { 雄 }\end{array}$

211 可逆的思考と弁別移行学習

一数量概念の発達にかんする研究 (2)一

香川大学 田中吉 資

212 量の保存に関する一考察

信州大学 土井捷三

213 集合の比較操作に関する研究 その 2

常葉女子短期大学町田イク

214 幼児の数概念について III

一その 1 ; 多少等判断課題の課題分析一

千葉大学 (1)三 浦 香 苗

215 一その 2 ; 多少等判断課題の反応型の分析一

玉川大学 (2)西 谷 さやか

216 多少等判断で用いる数操作の就学による变化

春日部市立沼端小学校 中 居 敬 三

\section{I 発表と討論の経過}

発表は規定通り行われたが，以下の 5 発表について は発表者より誤りの訂正があり, また説明の追加が あった。

中塚ら (210)については, 68 ページ右側下から 7 行 目の「BC」を「SR」に訂正. 69 ページ Table 1, 2 の 題名より「“すべで 条件における」を削除. また表中 の 7,8 才児の正答率は「“みんな”条件（被験者数は 18 名と 21 名）と"すべで 条件（21名と 19 名）の和 の平均であり，4，5，6才児の “みんな”条件のみのも のとは異なる」と追加説明. なお 7,8才児の条件別正 答率も示されたが, ここには掲載しない.

町田（213）の表 2 の括弧内の数值は正答者数を示す と追加説明.

三浦ら（214）の 77 ページ左側上から 8 行目「 $\mathrm{R}_{3} に$ よれば…...., $\mathrm{R}^{-}{ }_{1}$ や $\mathrm{R}^{-}{ }_{3}$ では…..」を「 $\mathrm{R}_{3}$ や $\mathrm{R}^{-}{ }_{3}$ によ れば…..., $\mathrm{R}^{-}{ }_{1}$ では……と訂正. また 11 行目に「 $\left(\mathrm{R}^{-}{ }_{3}\right.$ によれば(6)で誤答)」を追加.

西谷ら（215）の表中の推定される rule の反応型 12 の $\left\lceil\mathrm{R}_{2}^{1-} 」 を 「 \mathrm{R}_{2}^{-}\left(\mathrm{R}_{2}^{1-}\right)\right\rfloor に, \mathrm{~B}$ の $\left\lceil\mathrm{R}_{2}^{-}\left(\mathrm{R}_{2}^{1-}\right)\right\rfloor を\left\lceil\mathrm{R}_{2}^{1-}\right\rfloor$
に訂正.

中居（216）の表 II の課題 II の第 2 回目の $\mathrm{S}$ 群の結 果の上から 8 行目の人数を「3」から「2」に訂正.

また,フロアーからの質問に答える形で手続に関す る事柄で明らかにされた点は次のようであった。 中塚 ら（210）のテスト所要時間は 1 人平均 20 分であるこ と.土井（212）の補償性の正答は，「どうして高くな るの?」に対して「巾がせまくなっている」等である こと. 実験 II では強化は行ね;かったが, 正答の場合 には以下の試行は中止したとのことである.町田(213) の計数, 対応行動の中には視線のみで行ったものも含 まれているとのことである.

討論は順不同で行われたが，ここでは発表順にその 主要なもののみを挙げる.

久保田（209）については新田（東女大）より，「多 い分」を知覚的にきわだたせる工夫をしてはと，質問 と助言があった.

中塚ら（210）については小野寺（熊本大）より，2 条件を対比させる意義について，また 2 条件の差につ いて用語の差異と文型上の差異とが交絡しているでは ないかと，質問がだされ，“円はすべて青いですがな どの発問が設定できるはずと示唆があった。これに対 し共同研究者の高橋が "Are all the circles blue?" と いう質問の意味はどちらの表現の時によりょく理解さ れるかをみようとしたのであり交絡効果は考えなかっ たむね返答があった。

田中（211）に対し, 加藤（立教女学院）から, 弁別 移行学習の型に明確な発達差が見られないのは, これ らが学校教育等の環境的要因による影響が大きいから ではないかと示唆があった。

土井（212）については, 三浦より実験 I の同一性・ 可逆性・補償性の達成が異なるのは質問の形式による ものではないかとの質問があり，土井は解答の難しさ の水準の差は認めるが適切な表現を得ていないと返答 があった. 金子（東教大）は，高橋の可逆性の質問「も どすとどらなる」に対する「正答」を可逆性ありと判 定するのはピアジェが真の可逆性とみなす事態とはち がうのではないかと質したが，金子よりたしかにこの 「正答」にはいろいろの水準のものがあり得ると回答 があった。な補償性を保存成立の中心的要因と見な 寸ことに対して，また実験の提示効果についても，質 疑と討論があった。

町田（213）には，金子より，子どもに外的行為を引 
き出すために「同じ数だけ出しなさい」のような再生・ 構成課題を導入し両者の照合で子どもの反応を分析す るのも良くはないかと示唆があった。

西谷ら（215）に対して, 久保田から数の発達は単線 型ではあるまいと云われるが「単線型」といら考えの 具体例は何だろらかと質問があり，西谷より，ガニエ 流の, 最終課題にいたる一種類の数操作の形成過程を 考えるよらな場合であると回答された.

多少等判断に関連する問いとして, 近藤（東京精神 医学研究所）より，多少判断を求めるのに「多い方」 「少ない方」いずれをたずねるかでちがいがあるか, 多いと少ないの概念発達はどのようであるか，につい て質問があった．西谷は「多い」の方が早くから成立 するが，だからといってそれは「こちらがより多い」 という把握になっているとはかぎらないのでテスト作 成のときはそのような配慮が必要と意見をのべた。迫 （東学大）からは，英国の幼児の形容詞対（多い少な い等）の理解において差があると云われているが日本
ではどらだろらかと問題が出された.

「多いのはどちら」と「どちらが多い」の発問を幼児 は同じこととしてとらえるだろらかとの問いがあり， 吉武（東北大）から, 相対判断をたずねるには後者が よいようだとの意見が出された。

\section{II ま とめ}

ここでの発表はすべて論理・数学的概念の習得に関 するものであったが, 討論は主として健全な結論を引 き出すための実験・調查手続に関するものと, 概念習 得のために実際にどんな教示が有効かを知るためのも のであった。これらの概念が自然発生的に形成される ものではなく, 生育環境と働きかけの研究が重要であ るといら加藤の指摘に応えるという意味で討論中はほ とんど言及されなかったが中居の研究は興味深いもの である.

$$
\text { （久保田正人・三浦香苗） }
$$

\section{発達 (217～224）}

座長 滝 野伸子・横山明

217 積木分類課題における教え振り：母親と教師の 比較

一日米幼児教育研究 I一

神奈川大学 渡 辺 恵子

218 図形伝達課題における教え振り

一日米幼児教育研究 II-

$$
\text { 東京大学 } \bigcirc \text { 大 嶋 百合子 }
$$$$
\text { " 三宅なほみ }
$$

Stanford 大学 W.P. Dickson

219 幼児の課題達成行動におよほすす親の態度の効果 I 浪速短期大学 滝 野 伸子

220 乳児に対する母親の話しかけ

$$
\text { 扮茶の水女子大学 松 倉 信 }
$$

221 母子の言語的コミュニケーションの分析

一課題解決場面における teaching role の転換を 中心として一

和歌山信愛女子短期大学 末 田啓二

222 児童の言語伝達行動に対する役割取得の影響

一その 1 , 役割属性の教示と伝達行動の変化一

$$
\begin{array}{cccc}
\text { 愛知県立大学 } & \text { ○横 } & & \text { 明 } \\
\prime \prime & \text { 青 } & \text { 木 } \text { 民雄 }
\end{array}
$$

$\begin{array}{cccc}\text { 愛知県立大学 } & \text { 松 } & \text { 田 } & \text { 節 } \\ \text { " } & \text { 吉 } & \text { 野 } & \text { 要 } \\ \text { 宮城教育大学 } & \text { 本 } & \text { 屋 } & \text { 禎 }\end{array}$

223 物語受容過程の分析 (2)

一物語絵本の読みきかせ中の質問の効果一

東京教育大学 小林 幸 子

\begin{tabular}{|c|c|c|c|}
\hline 東京大学 & 無 & 藤 & 隆 \\
\hline " & 三 & 宅 & なほみ \\
\hline . & ○上 & 野 & 直 樹 \\
\hline
\end{tabular}
" ○田代康子

" 伊藤みね

" 佐藤和子

224 幼児に於ける質問行動

\section{I 討論経過とそのまとめ}

渡辺 (217), 大嶋ら（218）は一連の日米幼児教育研 究であり，まとめて討議に付された（217）は積木分 類課題，（218）は図形伝達課題における日米の母親と 教師の教え振りの比較文化的研究である.質問は(218) の「散文的記述と詩的記述」に集中した．その区分は 何によったのかといら問に対し，映画による言語記録 簿（日米）によったと回答があった，課題の図形によ る成績の差はあったか, 無藤（東大）といら問には, 
差はなかったといら回答があった。メッセージ・ュ ニットとコミュニケーション・ュニットとの相違，， ン・バーバルな反応も含まれるか, 末田（和歌山信愛 女子短大）といら問に対しメッセージ・ュニットの説 明があり，課題に対する反応ならばノン・バーバルな ものでも含むと回答があった．図形の名称について散 文的記述，詩的記述に分けたねらい，その違いの意味， 教育との関係がいずれの表現がよいか，本屋（宮城教 育大）といら質問に対しては，日米の討議の間で，双 方の言語構造に関し，米側より日本の表現は詩的だと いらことで用いた，アメりカでは分析的散文的教え方 の傾向があり，日本では物語りを作るなどして比喻的 な教え方の傾向がみられたと述べられた。佐藤（金沢 大）から散文的, 詩的といら分析カテゴリーの名称は, 教光振り論, コミュニケーション論からみると問題が あるのではないか，特に詩的記述というよりはむしろ メタファ，アナロジーによる記述である，その中での 関連づけの仕方のレベルの相違について細かい分析が 必要なのではないか, といら指摘があり, 教え振りの 日米の差にどういら影響を考えているか，といら質問 がなされた。共同研究者の三宅から，「散文的対詩的」 と「分析的対比喻的」とは分類の軸が多少違うと思う. 影響について，この場で答える段階ではないが，アメ リカと日本といら異なった言語文化圈それぞれの中で 有効な言語スタイルも異なるのではないかと考えてい る,とコメントがあった。

滝野 (219) は幼児の積木模様課題達成に, 母親が言 語的・動作的援助を与えらるような事態で, 親の態度, 援助の与え方を検討している.

課題遂行前の教示について田代（東京教育大）から 質問があり，母親が手伝ってもよいといら旨の教示を 与えたと回答があった. 渡辺（神奈川大）の分析の単 位・基準についての質問に対しては, 発表者から補足 説明がなされた，作業時間を制限しなかった理由，時 間の経過とともに母子双方のフラストレーションが予 想されるがどうか，末田（和歌山信愛女子短大）とい ら問に対しては, 出来るだけ母子相互の自由なコミュ ニケーションを観察したかったから.といら回答がな された. 最終目的と今回の課題達成行動に拈ける親の 態度との間の仮説は何か, 研究者と被験者との関係に ついて,被験者にはこの実験の意味を伝えてあるのか, 実験方法の論理性についてどら考えるか，金田（日本 福祉大）といら質問に対して，回答は，伝えていない. 研究成果が社会へ還元でき, 望ましい親子関係の形成 の一助となればよいと思っているが，難しい問題で, より望ましい研究方法があれば示唆を乞うという旨の
ものであった。

松倉 (220) は乳児に対する母親の言葉による働きか けがテレビの視聴によりどう変化するかを検討してい る.

吉野（愛知県立大）から, 子ども番組と, のど自慢 などの大人番組をみている母親の態度の違いはない か，みる番組が違えば母親の子どもへの㗢きかけも当 然違ってくるのではなかららか，それが母親の発語の 違いとなって出て来たのではないかとの疑問に対し て，子ども番組の時母親が子どもに話しかけ，大人番 組の時はほったらかしといらタイプもあれば，これと 逆のタイプもあるということであった，目的と被験者 への依頼と内容を変えているが実験方法の倫理性につ いてはどう考えるか，金田（前出）といら問に対して は，本研究の場合はこれでよいと思っている．研究者 と母親との会話の中で成果を返して行くようにしてい ると回答があった。

末田（221）課題解決場面に打ける teaching role 転 換した際にみられる母子の反応様式を言語的コミュニ ケーションの側から分析した研究.

渡辺（神奈川大）からの質問，カテゴリーをTask と Emotional に分けた理由, 浜名方式カテゴリーを減ら した理由について，ベールスのカテゴリーに準じて分 けた，発表者が再度分析しなおして，評定の一致率の 低いものなどを除き，上位概念カテゴリ一に分類した ので少なくなった，との回答があった.

横山ら (222) 児童の言語伝達行動に対する役割取得 の影響を検討した研究.

無藤（東京大） から， 3 年， 5 年の順序効果， 1 人の 被験者の答えた図形の数, 幾何学図形を選んだ理由, 被験者として 3 年生を選んだ理由について質問があ $\eta, 3$ 年生から 5 年生, 5 年生から 3 年生いずれも順序 効果はなかった。 1 人の被験者に伝達するために使用 した図形は 24 種類中 6 種類である. 知識の有無, 特に 明確に判断できる点で幾何学四形を用いた。用いた図 形は， 2 年ですでに習ったものと 4 年で習うものの 2 種類あるようにセットしたので被験者に 3 年生を選ん だ，と回答があった。 そして上野，三宅（東京大）か ら幾何学図形の知識をみているのか, 役割取得をみて いるのか明確でない，たとえ 5 年生から 5 年生の時に 「正方形」といい, 5 年生から 3 年生の時に同様に「正 方形」といっても， 5 年の被験者が相手の 3 年生が正 方形」を知っていると思っていれば一種の役割取得で はないか,といら指摘がなされた。

田代 (223) 物語絵本の読みきかせ中の質問の効果を 検討した研究。 
金田（日本福祉大）から，絵本「そらいろのたね」 を選んだ理由, 保育園との協同，内容面での教育的方 向とのつながりについて，子どもがどういう内容を獲 得しているのか, といら問に対して，特に理由なく今 まで研究に用いて来たのでこの絵本を使用した。保育 園との協同については直ちにといらわけにはいかない が，して行きたいと思っている．読みきかせ中に子ど も達が言い合い，その中で焦点がしぼられてきて，新 しい感動が生まれてくると考えるとの回答.

\section{発}

座長 三宅 和 夫・大 滝 ミドリ

225 自由描画場面に打ける父・母・子の相互作用の 発達的変容について（その 3 )

東京家政大学生活科学研究所 大 滝 ミドリ

226 発達初期に打ける母子交互性に関する研究 (II) 一予備的検討

\begin{tabular}{|c|c|c|c|}
\hline 東京学芸大学 & ○高 & 橋 & 道 \\
\hline 日本女子大学 & 古 & 澤 & 頼 \\
\hline " & 石 & 井 & 富美 \\
\hline " & 福 & 田 & 陽 \\
\hline " & 小 & 林 & $\Rightarrow$ \\
\hline
\end{tabular}

227 母子関係の成立過程と乳幼児のパーソナリティ発 達 (7)

一(その 1$)$ 就学前期 3 年間の母子相互作用過程分 析一

北海道大学 浜 名 紹 代 228 一(その 2) 特性評定法による母子の行動特徵の縦 断的分析一

北海道教育大学 $⿴$ 一井博 229 一(その 3) 小学校低・中学年に拈ける母子関係の 分析一

北海道大学田島信 元 230 -(その 4) 3 歳以前の子どもの特徵と母子関係一 231 母子の物理空間と心理空間の関係

北海道大学 三宅 和 夫

- (その 1$)$

- (その 2)

日本女子大学児童研究所

高 橋 たまき 大和田 保 枝 (1) 福 山 清 藏

藤 崎 真知代

\section{II ま と め}

成人対子ども，子ども同志のュミュニケーションが 共通のテーマであり, 方法論および測度の設定方法に ついて討議が行われた。一定の結論に達したとはいえ ないが, 今後共通の課題として研究を進めて行く上で のコンセンサスを探る上では役立ったと思う.

（滝野伸子・横山 明）

\section{$(225 \sim 232)$}

日本女子大学児童研究所 (2)渡 辺 真理子

\section{I 発表と討論の経過}

（225）は子どもの年齢が 1 歳 6 か月より継続して 行っている父一母一子の 3 者の相互作用の分析を目的 とした研究の 3 歳 4 歳の部分についての報告であ る. 古沢 (日女大) は, 相互作用の発達的変容とはど らいうことなのか, もし発達の方向について仮説があ るならば, 示してほしいと質問したが, この研究はた だ $1 つ の$ 事例について 3 者関係が子どもの発達ととも にどのように変化するのかを記述することを意図した preliminary ものであるとの回答があった.

(226) は生後 72 時間前後の新生児期の行動評定と出 産前 1 か月の母の心理テストにより母・子の個体的特 徵を把光，母一子交互性が 3 か月までにどのように展 開していくかを 3 事例について検討したものである. 岡（聖心女大）からはこの報告は 3 か月までであり， 行動評定のカデゴリーがかなり限定されているが，こ の先継続していく場合 6 か月ごろからは乳児の行動も 複雑になるだけでなく機能的な変換があるので表面的 に同一行動のように見えても，その行動をめぐっての 母子の機能的関係は初期のそれとは異質のものと考之 なくてはならないが, 同一のカテゴリーを用いるとい らことは問題であるといら意見が述べられた。 また野 口（明治学院大）は，母親の MFF p TPI に対する反 応と実際に乳児に対しての反応性や不安の度合とにど のような関係があるかを検討する必要があるというこ とを指摘した。

（227）（230） は発達初期から約 10 年間にわたって の母子関係と子どもの行動発達についての縱断研究の 第 7 報であるが，今回は 7 例について子どもが小学校 へ入ってからの母子関係を相互作用場面に拈いて把充 
た結果を中心として，それとの対比において同じ事例 の就学前 3 年間における母子相互作用過程, さらに 3 歳以前の母子関係の成立過程や子どもの特徵との関連 を検討した結果についての報告がなされ，この間に一 貫した母子関係の特徵が見られるといらことが指摘さ れた. まず岡から，発表された事例は一貫して「のぞ ましい」,「のぞましくない」母子関係が展開している 例であるが, この種の研究で興味あるのは, 初期にお いて同じょうに「扱いにくい子」の特徵をむつものが, 母のかかわり方の差によって「のぞましい」のでまし くない」母子関係になっていく過程,つまり「関係に よるパーソナリティの変動」ということではないかと の意見が出され，これに対して発表者の 1 人である三 宅から，扱っている全事例のなかにそのようなタイプ のものもあることを具体的に述へ，今後詳細に分析す る予定であるとの回答がなされた，奥平（埼玉厚生専 門学院）は，長期間にわたって同一事例を対象とする 場合の研究者との間の相互作用という問題とかかわっ て, 特に「扱いにくい子」,「のぞましくない母子関係」 の場合など，研究者が第三者的にかかわるだけでよい だろらかといら疑問を投げかけた。 三宅は，自分たち の研究に扒いては, 初期から小児科医による健診を含 め, データ収集の機会には当然必要な示唆を母親に与 えているといらこと，また研究者の影響を排除するこ とは不可能であり，どのような影響を受けるかという こと自体が興味ある問題であると述べた. この研究が 母子の相互交渉場面のみを扱っていることと関連して 岡は, 子どもの発達とともに, 特に学童期になれば, 子ども同士の集団にお゙ける行動を扱らことの重要性が 増してくるし，そこでの子どもの行動と母親との関係 における子どもの行動の関連を検討することが必要で はないかと述べたが, 三宅はこの研究で就学前 3 年間 においては子ども同士の自由あそび場面での観察も
行っていること, さらに今後小学校での相互交渉も把 えたいと回答した。

（231）（232）は2 組の母・子（幼児）について母 子が共同で遊ぶ場面を構成して, 行動観察によって, 母子の物理的空間と心理的空間とを相互に対応させる ことが，ある程度可能であると報告した.

古沢（日女大）は，観察の視点を定めること，すな わち中核的な構成概念を中心としてそれに直結すると ころから見ていくといらことが必要ではないかと指摘 した.これに対して, 共同研究者の 1 人である高橋は, 母子関係を把える場合, はじめから重要な变数をきめ ることができるのは, ある程度研究が進んでからであ り, 初期においてはそうした変数を見つけるといら試 みが必要ではないかと述べた。

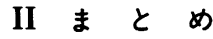

この部分で報告された 4 つの研究はいずれも比較的 自由な（母子（父母子）の相互交渉関係を扱ったもの である．相互関係をどのように把えるかといらことに ついてそれぞれ苦心をしているが，さらに方法的に洗 練される必要があろう．また個別事例的な方法をいず れの研究においても用いているわけであるが，それだ けにどのような事例をえらぶかということも検討しな くてはならないと思われる. 個別例的に綎断的に研究 していくことは発達の因果関係の問題に接近するため に大切なことではあるが, 単なる事例報告に終らせず, 他の研究者の参考となるような問題を明示するために は，概念化への試みがなされるべきであるという指摘 が波多野（独協大）からなされたが，そのためにも同 じような研究をしている者がじっくりと資料を出し あって意見を交換することが求められるのである.

（三宅和夫）

\section{発}

座長 野 村庄 吾・飯 島 婦佐子

\section{3 (発表取消)}

234 熟慮性は就学レディネスの一側面か

\section{独協大学 ○波多野}

和泉短期大学 稲 垣

235 認知スタイルの変容可能性について

一直接教示によるストラテジーの訓練一
誼余夫 佳世子

\section{$(233 \sim 240)$}

名古屋大学 ○宮 川 充 司 " 大野木 裕 明

236 乳児の操作的探索における新奇刺激の効果 一視覚と手操作の関係一

名古屋大学山田洋子 237 幼児に拈ける視覚的探索活動と眼球運動 I 京都教育大学 野 村 庄 吾 238 幼児における知覚的探索 
揲茶の水女子大学 毛 塚 恵美子 239 幼児の探索的学習に及ぼす好奇心の効果

和泉短期大学 稲 垣 佳世子

240 選択行動における新奇情報と親近情報の効果

東横学園女子短期大学 飯 島 婦佐子

\section{討論要旨}

本分科会は，不確定性の高い刺激に対する情報処理 過程の研究より成る.

(1)，熟虑型 ( $\mathrm{R}$ 型) と衝動型 (I 型) の認知的スタイ ルを扱った研究 (234，235) と, (2)，広義の探索活動

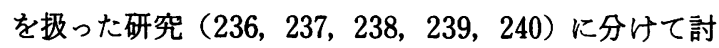
議した。

認知スタイルの問題に関しては, 従来は, その妥当 性を検討する研究が多くみられたが，今回は， $\mathrm{R}$ 型, I 型を就学レディネスとして問ら研究 (234) やストラ テジーの変容を試みる研究 (235) がみられ, この領域 の発展の方向を示唆していると考えられる.

234 (波多野) について, 岡本（京教大）はMFF と 学業成績の相関が幼児より小学校 3 年生にかけて変化 することが示されているが, MFF そのものの縦断的 資料はないのかと質問した。発表者より反応時間, 誤 数の変化について説明がなされた。 また, 結城（中京 大）は, MFF と学業成績の相関がでても選ばれた学科 が国語や理科であったための結果にすぎないのではな いかといら指摘をした。重ねてこのような問題につい ては,特定教科との相関をみるだけでは不十分であり， 児童の精神構造の分析を試みることが必要であろらと 主張した。これに対し，発表者より，Kazm の基準を 用いて把握した R 型, I 型の次元が他の何と関係があ るかを検討していると答えられた. 結局, この次元を 認知スタイルとして用いるか, あるいはもっと一般化 させて用いるかは, 研究者の問題意識によるといえよ 5. 臼井（北教大）は, 熟慮性が認知発達の指摘とな るのがせいぜい 1 年までという critical point は早い のではないかという指摘をし，この場合に，熟慮性の 発達の規定要因も考慮に入れてサンプルを抽出する必 要があろらとし, さらに, 熟慮性と educability の発達 との関連の概念化についてと, open-education に拈け る子どもの MFF テスト結果はI 型が多いという所感 を述べた。ここにも, 認知スタイルに及ぼす教育効果 の問題があると考えられる.

235 (宮川) に対して, 岡本 (前出) は, 認知スタイ ルの変容のためのストラテジーとして「より熟慮型」 の方向へ変えることだけでなく「より衝動型」の方向 へ変えるストラテジーも考えてもよいのではないかと
いら問題提起をした。百井（北教大）は，そらいら研 究は，まだ行ったことはないが，情報処理のストラテ ジーを変えるトレーニングといら点から考えれば，意 味があると述べた。 な掐井は，ストラテジーの変 容の研究は, すべて I 型から $\mathrm{R}$ 型への変容の試みであ るが, この理由として, I 型の子どもは知的な発達や認 知的パーフォーマンスに劣る傾向があるといら現実を ふまえた教育実践上の要請があることを指摘した．最 近の研究よりみると, R 型と I 型との間に, 視覚的情報 処理のストラテジーの差異があると思われるので, 単 に反応時間を速くする訓練だけでは意味がないと主張 した.

認知スタイルの一般知見として，アメリカの研究で は, I 型は発達が遅れていて R 型は優れているといら 考えがあり，一方，日本では，両タイプに意味を認め ようとする傾向があるという指摘が波多野（独協大） からなされた。このよらな知見にたてば，各タイプに 適合した教授法を考える必要があろら。また，野村（京 教大）から，測定法に関して，反応時間や誤数の指標 だけでなく，他の指標を考える方が生産性が高いので はないかといら質問があった。認知的な $\mathrm{R}$ 型, I 型と， 社会的な $R$ 型, I 型の関連についても討議がなされ, 直 接対応はつかないといら知見が得られていることが述 ベられた.この点については, 233 の研究が発表された らより討論が深まったと思われる.

今後の問題として，どのようなストラテジーを持っ た子どもに，どのような情報を与えたらよいかといら 問題は, この領域の生産的な方向の 1 つではないかと 思われる.

探索活動は，最近盛んに研究が行われている領域の 1つである. 本分科会の発表でも乳児から幼児を対象 として, 視覚的な微視的なレベルで把握した研究から 手操作などの行動的レベルで把握する広範囲の研究が みられた。この研究の多様性は, この領域が将来性を もつ領域の1つであることを示唆している.

236 (山田) に関しては, 発表者より適切な分析方法 について質問がなされた，波多野は，特に非言語的行 動の分析は困難であり, 現在は, 時間, 行動の出現回 数を用いて帰納的に整理していく模索の段階ではない かと所感を述べた。野村から，体の位置，手のあげ方 などの微視的な分析を行ったあとで統合的に考えてい けばよいのではないかといら示唆があった。ささらに, 丹羽（東洋英和短大）は，フィルム，アナリシスは分 析して数量化すると同時に全体的な印象を把握してい く折克法をとらざるを得ないのではないかといら指摘 をした．重ねて丹羽は, レジメの「従来の人見知り研 
究者が……」のステートメントに対する発表者の解釈 について質問した．特に，発表者が人見知りを否定的 に把握している点を指摘して，人見知りは肯定的な意 味も含むことを主張した。

237 （野村）に対しては，測定法に関する質問がなさ れた. 発表者は, 従来の eye camera とこの研究の測定 法との比較を述へ，幼児にとっては束縛の少ない本研 究の測定法は，より有効市ることを主張した。

240 (飯島）に対し, 結城（中京大）は, 新奇性, 親 近性は, 四形のもつ性質でもないし, 提示回数の問題 でむなく，主体の側の問題であるから，情報理論的観 点からは把握できないと指摘した。発表者は，新奇性 の指標として，主体の情報に対する認知的標準より規 定する方向をとっているといら説明を補足した。この 質問は，240に対するとい5よりむしろ，本分科会のア
プローチに対する批判であり, 研究者の問題意識のあ り方を問ら深い意義を含むが，そこまで討議が深めら れず，残念であった，その他，山口（学大）により, 認知的標準関する質問がなされた。

なお，238 (毛塚) に関しては，2，3歳の達成群，非 達成群間の差などの細かい質問がなされた. 239 (稲垣) に対しては，仮説と結果との関連について質問がなさ れた.この二論文については, 特に深く討論されなかっ たのは遺惑であった。

全体に field の好奇心が認知スタイルに置かれてい た. 時間不足のため, 研究の今後の発展の方向まで言 及できなかった，結城の指摘のように，問題の本質に かえって考察することの重要性も痛感された。

（野村庄吾・飯島婦佐子）

\section{発達（241～248）}

座長馬場道夫・柴田幸一

241 思考中の脳波

大阪大学 柏 原 恵 龍

242 ОбчуеНИе (Verkehr) の発達に関する研究 (1)

一その理論的枠組について一

姫路工業大学 青 木 讶子

243 練習による行為の短縮について

東北大学 柴 田 幸 -

244 技能の習熟過程に関する研究

一製図技能に括ける投影一構成行為を中心として (1) -

九州大学 城 七

245 幼児における感覚活動から思考活動に移る因子

ありや

一主として質問形態の言動における一

立教女学院短期大学 加藤 常 吉

246 幼児の象徵機能の発達 一虚構的行為モデルの再

現に拈ける手指の象徵的利用を中心に一

東京教育大学 河 崎 道 夫

247 就学前児の「みたて」の発達 一特にあそびとの

関連で-

248 理解過程に関する基礎実験

東北大学 辻 野 直子

茨城大学 馬場 道 夫

\section{I 討議の状況}

発表内容は, 思考・認識に関するものにほぼ統一さ れていたが, 問題に対する接近法, 被験者は極めて多 様なものであった．しかも，発表者以外の分科会出席 者は, 数人といら状況であった. それにもかかわらず， 質疑・討論は活発であり，予定時間を十数分過ぎて終 了した.

討議に当たって座長は,「(1) 思考過程をどのように 捕えるのか。(2) 思考・認識の発達はどのようにして 行われるのか.」といら2つの観点を定めて, この観点 から討論が行われるよう希望を表明しておいた．実際 には，座長の意困は，必ずしも実現していなかったよ らであるが，この観点から発表内容に関する討議を整 理して報告する.

\section{II 討議の概要}

思考過程をどのようにして捕えるかの問題に関係が 深かったのは, 柏原, 柴田, 馬場の発表であった. 柏 原の研究は, 脳波と知能テスト問題のタイプとの関係 を見たものであったが, 1 人の被験者についての 1 回 の実験であったために, 現象が疲労と独立でない点が, 馬場より指摘された。 また八重沢（筑波大）より，問 題のタイプによる効果ではなく, Activation の効果が 出ているのではないか, また周波数と発生部位を関係 つけることについて疑問が提出された，発表者から， 
課題によって覚醒水準に差があるとはいえるという回 答があった。

柴田の発表は電気回路の問題について「思考過程の 図示分析」を行ったものであった。 ガルペリンの理論 に十分沿っていない(城), 思考に省略の生ずるのは当 然である (河崎・馬場) 等の指摘があったが，方法そ のものについては興味が持たれた.

馬場の研究に対しては, 学力テストの成績判定が 1 人の評定者によっている点, 理解「過程」の研究にし てはstatic な方法であるとの批判があった(城), 報告 者からは, 短期間の理解過程の研究には, このような 方法はまちがっていないし，あってもよい。この場合 1 人の評定者によることは止むを得なかったと返答さ れた。

この他の研究についても思考研究法と関係のないも のは当然ない訳であるが，特に思考の問題の研究は, その思考内容の質と行動・表現の関係が定かではな く, 研究法の問題が常に重要な問題として潜んでいた と思われる. この点について青木の ОбчуеНИе の発 達の研究法について質問があったが(城), 発声, 発語, 微少反応で研究したといらことであった．加藤の発表 に対しては，他人との情動的 Communication を欲す るためと考えられる部分もあるといら意見が过野より 述べられた，加藤は，その通りであるが，その communication の中で思考訓練が行われていると観るべ きだと答えられた。城の研究に対しては，森（職業訓 練大学校）より総合行為などについて質問があり，プ ログラム内容, 総合行為の意味について説明がなされ た.しかし，上記の討論では，用語や説明の共通理解 が十分でなく，討議は多くの問題を残しているように 思われた。

河崎・过野の研究に対しては，まとめて質疑が行わ れた,いずれも幼児の象徵機能に関するものであった。 河崎に対しては，保育園間に違いがあるかどらか辻野 より質問があり，これに対して違いは調べていないと いらことであった。このため, 園児同志のあそびの伝 えあいの可能性が問題として残された。 また，辻野に
対しては，河崎より，あそびの「中」「外」を分けてい るが，行為動作と言語的質問に分けた方がよいという 指摘がなされた，过野は，質問状況と行為状況に分け ることに同意したが，あそびが子どもの象徵機能に影 響するといら観点は重視したいといら意見であった。 河崎, 过野両者に対して, 横山（和光大）より，みた て行為（象徵機能）を単に 1 つのみたて行為と分類す るのでなくより具体的にどのようなみたて行為で あったか，細かく分析・記録すべきであると意見が述 ベられた。

以上の質疑・討論は，いずれも方法的なものに重点 があったが,これらの問題の背後には，意識や思考な ぞの内的過程を知る難しさの問題があるように思わ れた. 箱田（九大）より,「ある想像的行為を行ら際, 年少幼児では事象を支えもし，年長幼児ではその支え なしに行う，という仮説は，具体的にどういった実験 によって証明されるかという質問が，河崎に対して提 出されていた．これに対する回答はなされる時間的余 裕がなかったが，一般的にも方法論的に重要な問題を 提出しているように思われる. 端的にいって, 研究が 主観を客観化する方法を要求するとすれば，それはど のようにして行われるのであるか. 今回の諸発表も， そのいくつかの試みを提出しているといら意味で興味 深いが，いずれの研究もこの点に問題を残している. 勿論, この問題は, 心理学にとって永遠の問題であろ らから，完全を期すことは現在のところ不可能であろ らが, 最善を行ら努力は更に要求されているように思 われる.

なお，いかに思考の発澾が行われるかについては, ほとんど討論が行われなかった。このことは，思考の 研究が, 更に明確, かつ厳密な方法で, 通時的に行わ れなければならないことを示唆するものであろう。

付記 座長は, 質問のほか, それに対する回答をも 用紙による要旨提出を求めた。この結果, 両者合わせ た用紙枚数は， 20 達に達した. 今回の討論報告は, こ れらに基づいたものである.

（馬場道夫）
発

座長 山口勝 己・那 須 光 章
250 Multiple-cue Probability Learning における幼 児の判断特性

249 アニミズムに関する研究

三重大学 市川千秋
京都大学 土居 道 栄 
東京成徳短期大学 小林 厚子 252 因果認識の発達に関する研究 (IV) 一特殊な質問 形式による先行経験のおよぼす効果一

大阪教育大学 山口勝 己

253 大小関係の一般化過程の発達について（1）

東北大学 熊 谷 高 幸

254 道徳判断の発達

-Kohlberg 理論に基づく質問紙の作成一

$\begin{array}{crrr}\text { 東京大学 } & \text { ○山 } & \text { 岸 } & \text { 明 } \\ \text { " } & \text { 無 } & \text { 藤 } & \text { 隆 }\end{array}$

中野区立大和小学校 堀 野征

255 幼児の道徳的行動に及ぼすモデルの行動とその結 末の効果

一Resistance to Temptation を指標にして一

東京大学 桶 口一 辰

256 子どもの善悪判断における発達と観察学習の効果

（II）一般化・代理強化に視点をあてて一

大阪大学 那 須 光 章

\section{I 発表と討論の経過}

本分科会では, 上記 8 題の発表が行われた. そこでと り扱われている内容はさまざまであり，いくつかのブ ロックにまとめることが困難であったので, 討論にお いては個々の発表について順序不同で質疑応答が行わ れた。 各発表の概要およびそれに対する質疑応答を以 下に記す。

まず市川（249）は, 老人のアニミズム生起傾向を(1) 性, (2) 知的能力, (3) 教育歴の 3 要因から分析し, さら に老人のアニミズムのもつ形態的側面を理由分析から 明らかにしようとした。 これに対して山口（大阪教育 大）から (1)「死んでいると判断するものる広い意味で のアニミズムとは言えないか」, (2)「Piaget は幼児を対 象にしてアニミズムを研究したが，老人のアニミズム を研究する意義は何か」といら質問がなされたが，市 川は第 1 の質問に対して「アニミズムそのものとは言 えないが, 問題のあるところである」, 第 2 の質問に対 して「老人になれば幼児にかえるのではないか，すな わち発達における退行現象を明らかにすることができ るのではないか」と答えた。また那須（阪大）から「視 覚・聴覚異常を訴える老人などを被験者から除いたと あるが，アニミズムの原因として知覚的な要因も考光 られるのであるから，むしろ視覚異常などのある老人 を被験者とすべきではなかったのか」という質問がな されたが，市川は「Piagetによるとアニミズムは精神 構造の反映であり，しかも正常人にみられるのであっ て視覚異常等とは次元の異なる問題である」と答えた。
土居（250）は, 幼児が判断課題において複数情報か らくる手がかりをどのように使用するかを, 各々の手 がかりの外的基準 (Cue Validity)の異なる課題構造と の関連から検討した。

小林 (251) は, Piaget の研究等にみられる「子ども は，偶然的なできごとというすのを考えない」といら 規定の仕方が，やや一面的すぎるのではないかといら 疑問から, 幼児に対する㬰験を通じて, この規定の不 十分さを論証しよらとした。

山口（252）は,「なにが (What…...)」あるいは「だ れが(Who……)」といら言葉で始まる2つの特殊な質 問形式による先行経験が, 後続の一般的な「なぜ (Why……)」による質問形式によって, 同一の対象に ついて行われる質問の解答におよほすす効果を検討し た.

熊谷 (253) は，具体的で特殊的な二者(パパと赤ちゃ ん）もしくは拀ちゃんを加えた 3 者に大小関係を有 する様々な日常的素材を対応させることによって, 大 小関係の一般化の過程を検討した.

山岸（254）は, Kohlberg 理論に基づく道徳判断に ついての質問紙を作成し，自発的な判断（自由記述に よるもの）との比較, 年齢による発達差により結果を 分析し，質問紙の妥当性，信頼性を検討した。これに 対して, 土居 (京大) から選ばれている kohlberg の例 話は被験者の年齢や認知発達水準と関連性があるの か, 高橋（科学警察研究所）から回答の選択を作った 基準は何か, 選択肢を用いて行うには無理があるので はないか, 岩佐（モラロジー研究所）から選択肢法に よると児童の現在の段階よりも上の段階を選ぶ傾向が 出てきて現段階を必ずしもとらえられないという問題 があるのではないか, 二宮 (名大) から stage 5,6 の違 いについての質問がなされた。これらの質問に対し, 発表者は, 現状での道徳判断質問紙のもつ問題点をど こまで少なくさせることが出来得るか今後更に検討を 加えたいとした.

桶口（255）は，モデルの行動（誘惑に負ける行動） とその結果を観察することが, 直後の類似状況での被 験者の行動にどのような効果をもつかを検討した。こ れに対して, 松田 (愛知教育大) から自己批判 $\mathrm{M}$ 群で はモデルの自己批判的コメントを十分に注意を向けて とらえることができなかったのではないか，岩佐から 実験者はこの実験で誘惑に抵抗し得た子どもを道徳性 において高いと考えているのか, 春木（早大）から operant level を取る必要があるのではないか, といら 質問がなされた. 発表者は道徳的行動と断定できる程 のものでもなく, 遵守行動と言い換えてもよい, また, 
誘惑の測度として接触時間だけでは不十分であるだろ らと述べられた。

那須 (256) は, 観察学習による善悪判断の変化を課 題の種類, 判断原理の学習の度合, 代理強化の有無, 効果の持続等を組合せて検討した. これに対して，高 橋および山岸（東大）から観察学習の効果すなわち般 化されたといら意味は認知構造に変化がおきたといら 意味でとらえて良いのか, 二宮から観察学習の効果が 持続するならば結果論判断モデルの観察において多分 に倫理的問題が含まれているのではないか, 小久保(埼 玉・川本中学校）から観察学習が教育現場の中で観察 指導に効果をあげるにはどらしたら良いか，大西（新 潟大）から代理強化者との人間関係が代理強化にどの ように影響するのか，松田から盗みとうそにおける影 響の時間的差について質問がなされた。これらの質問 に対して発表者は, 認知構造の変化が生じたとは言い 難いが, 行動的, 言語的変化が認知構造に対して何ら
かの影響があるのではないか, 教育現場での観察指導 に関しては十分な資料とはならないが，善悪行動の直 接的説諭や賞罰だけにたよるのでなく，子ども達の観 察力の鋭さをもっとうまく利用できるのではないかと の返答があった。

\section{II ま と}

本分科会では, 認知発達におけるいくつかの重要な 問題についての研究報告が行われたのであるが，座長 の進行のまずさなども手伝って討論内容が比較的かた よってしまい, 方法論上の問題や倫理的問題が論議の 中心であった. もちろん，上記のことも重要な問題な のであるが, 各研究の位置づけあるいは意義といった ことを認知発達研究といら巨視的な観点から討論が潹 められたならば,ささらに意義深いものになったものと 思われる.

（山口勝己・那須光章）

\section{発達（257～264）}

座長 吉田泰子・高木和子

257 助詞「は」「が」の獲得

一自由再生課題を通して一

怙茶の水女子大学 秦 野 悦子

258 幼児における口頭作文の研究 II

北海道教育大学 藤 友 雄 暉

259 幼児の文の構成能力について

260 言語習得過程の分析

東北大学 黒 田吉 孝

ーシンタックスについて（その8）-

青山学院女子短期大学 吉田泰子

261 言語発達研究 (2)

-reduction の心理学的意味について一

東京都立大学 岩 立 志津夫

262 幼児の継時的情報処理に関する研究

一継時的処理能力の測定一

$$
\text { 山形大学 高木 和子 }
$$

263 名詞連語の発達の初相

九州大学 綿 巻徹

264 幼児の単文理解及び模做に扣ける語順依存

東京教育大学 鈴 木 情 一

この部屋での発表は大きく 3 つに分けることができ
よう. 第 1 は, 泰野, 藤友, 黒田がとりあげた発信事 態に怙ける日本語の助詞の習得についての問題であ る. 3 発表とも実験的に発話事態を設定し, 幼稚園児を 対象に助詞の使用の発達を検討している. 第 2 のグ ループは, 吉田, 岩立, 綿巻によるもので年少幼児の 自然な発話を記録し，分析・記述することにより言語 発達における法則性を見出そらとするすのである. 吉 田はChomsky の生成文法理論に, 岩立は Fillmore の 格文法理論に分析の視点を依拠しており, 綿巻は名詞 連語に限って論じている. 第 3 は, 鈴木がとりあげた 文理解と語順との関係についてであり, 高木の研究は 直接的には言語を扱っていないが同系列に入るすので ある.

討論は, 吉田の発表の補足から始められたため第 2 のグループのものが初めに論じられた. 質問との関係 をも加えてここでの討論内容をまとめてみたい.

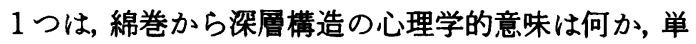
なる記述のための道具にすぎないのかといら質問がな され，深層と表層といら用語の定義についても吉田か ら岩立に質問がなされて討論の口火となった. 岩立は, 深層とは発話にあらわれる（表層に至る）前にすでに 成立している言語的な構造と定義し，それは子どもの 認知的活動の発達の中から言語的構造へととり入れら れて確立していくものであるとする. そして方法論的 
には，発話の分析を子どすの活動との関連すなわち場 面的意味情報をる加えながら解釈し，深層の構造を推 定する.ここでは，深層構造が成立していても子ども の中に何らかの行動上の制約 (例えば Memory span) があるために表層としては不十分な形式でしか表われ ないのだと考える. 吉田の場合は, 生成文法理論に基 づき，子どもの発話を説明しらる涀則の体系としての 深層構造を追求している.この点で純枠に帰納的な方 法とは異なるが，現象をどの程度よく説明できるかが 問題なのであるとしている. この点で，発話分析から 推論されたルールの記述については，ルールを現実の 生戍過程にあてはめる場合にある程度の制約を設ける ことが必要になるのではないか，そらしないと現実の 子どもにはできないよらな複雑な表現形式も生成可能 と考えてしまらといら指摘もなされた。吉田は, 現段 階では表層に移行する際の変形ルールについて手がつ いていないが，その時点で考えなければならない問題 であろらとし，岩立は，発話意図の複雑度の範囲から 自然に制限されてくるはずであると述べた. 白井（聖 心女子大）の「印欧語圈でつくられた言語理論，特に 句構造文法的なるのを日本語にそのまま適用すること についてどのように考えるか」という質問に対し，岩 立は格文法モデルを用いた場合, 意図の構造について は共通性が高いことから，表層でのルールは異なって る意味的にはこの理論を導入することに問題はないと 述べ, 吉田もChomsky の句構造文法よりも Fillmore の格文法の方が日本語の構造記述に適しているといわ れているとのべた. 綿巻は, こうした深層構造を記述 するメリットは何か, 記述のためだけなら意味的なも のをとり入れれば表層からだけでも記述できるのでは ないかと指摘した。 それに対し吉田は, 従来の日本語 の syntax の体系的記述の方法は意味的なものが輻湊 しているので利用できないと考えていると述べた，岩 立は格文法から表層にあらわれてくる以前に意味的に はわかっていることが指摘できれば，言語治療などの 臨床面にも向らことができるという考えをのべた.

第 2 のグループの論点をまとめると，1つは，「は」 と「が」の発達差についてであり, も5 1 つは, 助詞
の脱落についてである. 前者は, 秦野の発表をめぐっ て行われ, 岩立から, この差についての心理学的意味 をどうとらえるかという意見が出され，秦野は，「が」 は格関係として安定しているためではないかとのべ た。ささらに大久保（国立国語研）む同じような結果を えたことが述べられ，子どもの対象のとらえ方とのか かわりという点で知能とのかかわりあいがあるのでは といら意見がのべられた。助詞の脱落・誤用問題は藤 友の発表を中心にとりあげられ，岩立が動詞との関係 で学習するために起るとは考えられないかといら指摘 に対し，やはり何かをつけなくてはという感覚を伴 なった試行錯誤の中でルールを学習していくと考えら れるとの答であった. 高木から，大人の例の発話中の 助詞の脱落や誤用との関係はないのか, そらした研究 を背景にもつべきではないかといら意見に対し, 藤友 は, 大人のデータをとる時は書かせたため脱落はみら れていないが，やはり大人の話しことばの現状をふま えた研究も必要であろらといら意見であった。また， 吉田から出された目的語に「を」をつけるかわりに「が」 を用いるといら誤用は，主語と目的語を明確に表現す ることができないためではなく，主語と目的語は助詞 がなくとも意味関係が明白なためではないかという指 摘には，やはり関係を明確に表現できないと考えるべ きではないか，心に占めているもののところに「が」 をつける傾向があったりすると答られた。この発展と して綿巻から，わかっていてもきちんと表現できない ということは，子どもの言語能力に欠陥があるととら えるべきではないか, 発話意図をくみとってわかって いるらしいと評価することをやりすぎてはならない, 適確な表現形式をとることを学習対象とさせるべき だ, この点で意味的なものと syntax とを平行させて 扱っていくべきだという意見がだされ一同の賛意をえ た.

高木の発表に対して迫（東京学芸大）から順序性の 記憶が言語理解にどんな意味をもつのかという質問が なされ，継時的な刺激として言語を考え，その理解の 柱として考えられる時間的な処理の基礎能力としての 位置づけを考えているといら答があった。

\section{発達（265～272）}

座長今泉信人・天羽幸子 265 子どもの異年齢交友に関する研究
-（1）異年齡交友の実態（1）-

福岡教育大学 (1)田 中 敏 明 広島大学 (2)今 泉 信人 
266 子どもの異年齢交友に関する研究

一(2) 子どもの異年齢児間交友に対する親の認識 と態度一

267 幼児のあそびの発達

福岡教育大学 岡 村 二 郎

一異年齢集団に拈ける自由あそびの観察一

はこぶね幼児教育アカデミー ○田 㴊創

関西学院大学 田中国夫

268 保育園児の対人行動の発達に関する研究 (3)

中央区教育研究所 $\bigcirc$ 三宅 篤 子

東京大学 牟 田悦子

269 双生児の相互関係 (2)

青山教育研究所 天 羽幸子

270 児童の社会的行動に関する研究 (IV)

一幼児に対する保育者の評価を中心として一

東京都練馬高等保母学院沢文 治

学習研究社 加藤 一 光

271 心理的行動空間モデルによる自然観察記録の発

達的検討 (1)

一自然観察法における厳密性の問題一

東京都老人総合研究所 守 屋 国 光

272

一幼児期に括ける対人行動の分析一

$$
\text { 早稲田大学 ○種村純 }
$$

東京都老人総合研究所 守 屋 国 光

\section{I 発表と討論の経過}

この部会での発表は大きくいって児童, 幼児の対人 行動をとりあげたものである.

田中（256）は異年齢間交友について小学校 5,6 年 生を対象にその実態と異年齡間交友への期待について 調査し, 学校内外のいずれの交友においても, 異年龄 間交友を望む傾向は大きいが，現実の交友は殆んぞ同 年齢間に限られるといら実態が報告された。今泉 (266) はこのような交友についての親の認識と態度を調查 し，異年龄特に上学年児との交友を望ましいと思って いると報告した．これに対し異年龄交友が望ましいと 考えられる根拠のよらなものがあるのかとの曾我（兵 庫医科大）の問いに対して，今泉は今回は実態の調査 のみにとどまったと答えた。

田㴊（267）は異年齢の幼児集団の自由遊び場面での 遊戯活動を遊具，仲間関係に視点を拀いて調へ，年龄 によって使用する遊具が異なり，静的な遊びから動的 遊びへ，ひとり遊びから協同遊びへ，また遊具の使用 す年齢と共に 1 つことに集中する傾向がみられると報 告した. これに対して幼児自身が各年齢集団に属して
いるといら意識を持っているのか（曾我）との質問に 対して,グループについては日常生活がずっとその組 わけで行動しているので，その意識はあると思われる と答えた.

三宅 (268) は昨年にひき続き乳幼児の対人関係の発 達を保育園での観察によって調へ，特に月齢は近いが 対人行動，環境に差がみられる男子 2 名について $2 才$ から 3才の対人行動と対人環境の関係を各働きかけと 相手の反応を対にして分析した結果を報告した。これ に対して高橋（国立音楽大）は対人行動は相手があっ てのことで，相手，子どす，先生といったとらえ方は あらすぎるのではないか. 対人行動は interaction と してとらえるべきだとすれば本人，相手のカテゴリー の出現率をばらばらに数えるだけでは関係を考えるこ とにならないのではないか. 連続行動を単位行動とし て分析してとらえることをどら考えるかと質問した。 三宅は相手が変れば対人行動が変るかどうかを含めて 発達的に検討しょらとしたのが我々の目的である. 即 ち対人的行動の未分化な状態から相手への働きかけが 分化して徐々に特定の相手が形成される過程をとら文 るといらことである. 対人行動が関係であるというこ

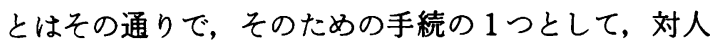
行動一相手の反応を対にしてその関係を検討したので あると答えた。

天羽（269）は双生児の相互関係の 10 年間の追跡研 究の結果, 相互関係の密蹯は乳幼児期に形成され, そ の後あまり変化なく, 密眯の形成にもっとも大きな影 響を与えているものは家庭での扱い方であると報告し た.これに対して田中は 10 年間同じような側面から調 べた場合，その反応は年齢によって同じ応をしても 意味が異なってくるのではないかと質問した。 天羽は たしかにそのような面があると思われるが現在の所, 現象としてどのように変ってくるか, 又変り方の速度 などが一般児と違うのではないかと思って，あえてそ のままの形でとらえていると答えた.

大場 (270) は幼児の社会的行動に関する表現用語に ついて，保育者による「好ましさ」といら評価の面か ら, 使用頻度, 年齢差, 性差などについて検討し, 行 動半径の払大が著しい幼児期では同じ表現用語でも年 龄差・性差によって評価の尺度自体の振幅が大きい場 合があると報告した。

守屋 (271) は観察者の主観がはいりやすいとされる 自然観察法は発達研究にとって重要な研究方法である が，資料収集段階では利点ともいうべき主観を交えて 現象を記録し，資料処理の段階で資料に混入している 主観を何らかのフィルターによって統制し, 考察の段 
階で再び主観を復活させることによって自然観察法の 厳密性の問題は解決されるのではないかと述べ，続い て種村 (272) はこのフィルターとしてすでに発表した 心理的行動空間モデルを用いて，2，3才児の対人行動 の分析結果を発表した. 土谷（国際基督教大）は対人 行動の研究で対人行動の型の变動が認められるとすれ ば，そこで問題にすべきはその変動にどのような条件 が関与するかをあきらかにすべきで，そのことが発達 をdynamicにとらえることになると思うと述べた。 こ れに対して守屋は発達研究であきらかにし得るのは年 齢に伴なってみられる発達的交代の傾向である，どの よらな条件が関与した結果として変化が生じたかとい 万発問は一見 dynamic といら印象を与えるが発達が 周知の条件以外の条件も加わった結果としての変化で
ある以上, 安易に dynamic という表現をしてはならな い.必要なのは発達といら本来的な性格を考虑した研 究態度であると答えた。

\section{II ま と め}

本部会は研究の対象から異年齢間交友に関するもの と, 対人行動とに大きく二分されたので, これらにつ いての共通の話題での討論が望まれたが，比較的研究 方法についての指摘などにとどまり，共通のテーマと して対人行動をいかによりよくとらえるか，継続研究 の場合の発達的変化をどのようにとらえるか等につい ては時間不足の感があった。

（今泉信人・天羽幸子）

\section{発 達 (273〜281)}

座長 山崎 愛 世・宇 野忍

273 幼児の描画過程の分析

東京教育大学 山 崎 愛 世

274 幼児の描画についての一考察

$$
\text { 搽の水女子大学吉田博子 }
$$

275 眼球運動を指標とする幼児の対象認知の発達と

教育

一その 2-
法政大学 乾

東北大学 ○長谷川 啓 三

立教大学 足 立 博 志

276 文字認知に関する発達的研究 (8)

大阪教育大学田中敏 隆

277 競争ゲームによる空間概念の形成

東北大学 立 木

278 児童の空間の認知に関する研究 (3)

早稲田大学 相

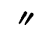

"

東京少年鑑別所

国立教育研究所

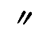

279 幼児の空間認知に関する研究

一幼児における地図導入の試み（1）-
(1)東北大学 宇 野 忍

(2) " 日 下 正 -

281 空間関係の認知に関する発達的研究

一風景課題を用いた地理的空間定位に打ける教 示効果一

$$
\text { 扣茶の水女子大学 中塚 みゆき }
$$

\section{I 全体的特徽}

9つの研究発表があった. 273〜275 は幼児の観察お 孝よび描画を扱った研究, 276 は文字認知を扱った研究, 277〜281 は空間概念を扱った研究であった. 277〜281 までの中には, 生活空間を子どもがどう認知している かを調べたもの（278）, 地図の問題を空間概念と結び つけて扱ったもの（279，280）などがあった．討論は 3つのブロック（273〜275,276,277〜281）についてそ れぞれ行われ, フロアから, 大西氏 (愛知学院大), 中 村氏（愛媛大）などが参加され，次のような討論がな された。

\section{II 討論の内容}

274 では知的リアリズムの問題が論議の中心になっ た. 立木氏から、コップを見せないで書かせた場合, フリーマンの言う内的知識が描かれると予想される が，そうすると内的知識の存在は否定できないがこの 点はどうか, との質問に対して, 吉田氏からそれは認 めるとの発言があった. 山崎から, ある対象 (コップ) を描く場合, 目の前にある対象(コップ)は表現のきっ 
かけでしかない場合があるのではないかとの意見に対 して, 吉田氏から，きっかけではなく、コップを描く 方向づけがなされると考えるべきだとの見解が示され た. 長谷川氏，山崎から、イメージをどのようなるの と考えるべきかについて意見が述べられた，その中で イメージと観察力との咸係，イメージと描画表現との 関係の問題が指摘された. またイメージの存在の証明 について論議があった。

273 に対して, 立木氏から, 触知覚と描画との関係に ついて，どのような因果関係を考えているのかという 質問に対して，山崎から描画の訓練をすると触知覚が 向上すると考えているとの答えがあった。

275 に対して立木氏から，この実験で 1 回目と 2 回 目では，絵がうまくなったといえるか，眼球運動につ いてはどらかとの質問があった。 長谷川氏から，絵に ついてはそら言えると思らが, 眼球運動については,

条件統制が不十分である点, 眼球運動の特徵的な変化 を取り出せていない点からいって, 眼球運動が向上し たとはいえない段階だとの答えがあった。眼球運動の 記録について, 停留点 (黒須氏), アイカメラで取った データとの対応（立木氏）などについて意見, 質問が あった.

276 に対して, 日下氏から, 図となる 2 文字の第 1 文 字に注目するような認知方略を考えてみることはどう かとの発言に対して, 藤田氏から，そのような方略が 使われたかどうかはわからない，今後，読字テストな どを併用して検討したいとの答えがあった。
279,280 に対して大西氏より，子どもが方向性を手 がかりとしているか，それとも，色のような事物的手 がかりによっているのかについて，子どもの動き，発 言の中で気づいた事実はないかとの問いに対して，日 下氏から，子どもが迷っている時があり，そんな時に は変化しない事物的手がかりを基準にする必要がある と考えられるが，はたして，子ども自身がその時，何 を手がかりとしたか明確ではないとの答えがあった。

277 に関して, 日下氏より，立木氏へ，3つ山問題解 決の十分条件は何か，との質問があった。これに対し て立木氏より，(1) 写真の回転について教示すること, (2) 背景をむっている写真を用いること, (3) 多人数で でき，しかも連続的な遊びを考えることがあげられた。 日下氏より，立木氏のうら十分条件を操作して子どす が 3 つ山問題を解けるよらになったとしても，その子 どもの遂行過程と大人のそれとは同じだと考えられる のかとの疑問に対して，立木氏ょり，同じであるかど らかはわからないが，まずこの問題の解決を規定して いる要因をさがすことが先決問題であるとの意見が述 べられた，中村氏から，従来の研究がとりあげた観察 の要因, イメージ訓練の要因などを考える必要がある. 自分は 3 つ山問題解決の十分条件は (1) 人形からの前 後関係がとらえられること，(2) ある位置での関係と 他の位置での関係を変換できること（基準系の照合） であると思らとの意見が述べられた。

（宇野 忍・山崎愛世）

\section{発}

座長 佐 野 良五郎・山 根

282 幼児期における「手の労働」に関する発達心理 的研究

一とくに手の発達と共同性について（その 3)-

徳島大学 (3) 山 尚子 徳島県立保育専門学院 (4) 米 隆子 283 一とくに手の発達と共同性について（その 4)284 乳児の行動パターンの発達に関する研究

一研究法及び観察法について一

佼成病院 ○佐 野 良五郎

" 佐々木 公子

2851 才高 D.Q. 坚の追跡研究

提節子

$(282 \sim 290)$

-3才時点における検討一

佼成病院佐 野 良五郎

" ○佐々木公子

286 乳幼児の保育内容に関する発達心理学的研究

愛媛大学玉 $川$ 公 代 287 モンテッソーリ教育法に関する一考察 (その 4)

一観察により園児の行動特徵をさぐる一 社団法人神奈川県私立 $\begin{array}{crrrr}\text { 幼稚園連合会 } & \text { ○滝 } & \text { 坂 } & \text { 信 } & \text { 一 } \\ \prime \prime & \text { 余 } & \text { 語 } & \text { 正一郎 } \\ \text { 上智大学 } & \text { 平 } & \text { 井 } & & \text { 久 } \\ \text { 早稲田大学 } & \text { 春 } & \text { 木 } & & \text { 豊 } \\ \text { 岐阜大学 } & \text { 伊 } & \text { 藤 } & \text { 秀 } & \text { 子 }\end{array}$ 
288 幼児における観察学習と模做反応 (III)

一2〜 5 才児に打ける発達的変化一

慶応義塾大学 ○望 月昭

和光大学 横 山 浩 司

289 障害幼児の心身の発達 III

一比較基準としての正常児の運動能力の実態的 研究一

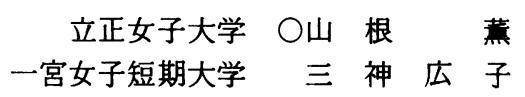

290 運動の調整力の指標としての跳下緩衝能の発達

京都教育大学 末 利 博

\section{I 討議経過}

各演者の発表時には 30 名〜35名の参会者がいた が, 討議にはいっては10名が参加した。しかし演者お。 よび参加者相互の間に熱心な討議が展開され, 15 時 15 分から 16 時 35 分まで時間の不足を感ずるほどに充実 した意見の交換が続けられた実り多い討議であった。

\section{II 討議内容}

佐野座長の司会のもと発表順に問題をとりあげ，討 議をすすめるといった方式がとられた．久米と丸山と は共同研究者である，幼児の「手の労働」を「遊びに おける道具使用」とらけとめ，その遊びが幼児集団の 共同性の育成にどうかかわるかに論議が集中した，滝 坂は「手の労働」とか,「共同性」とかの概念の整理が なされるべきことを強調した．同じく横山浩司（和光 大学）もこの $2 つ の$ 概念の間にどのような本質的連関 があるかを明らかにすべきことを主張した。 ささらに幼 児の集団人数と道具の数とを質問したのに対して，4 〜 5 人の少人数とそれぞれにゆきわたるように道具を 与えたこと，さらに鋭くない食事ナイフなどの道具類 を利用したことが答えられたが，なお明らかにすべき 条件の多いことが話しあわれた。

次に佐野は乳児の行動パターンの発達の実態を $3 つ$ の方法を通じて1つの全体像としてとらえることを目 指しているといい，これまでの心理学での乳児研究は 特定の現象たとえば微笑反応について解明をすすめて きた。これでは乳児の全体像を見通すことがむずかし いであろらという．山根は問診および母子交渉場面の 観察といら方法論に関して，あげられている観察項目 が真実に乳児の発達特質をとらえるのに適当であるか ぞらか, 観察にあたっての着眼点をもっと検討すべき ではないか，それがあってはじめて発達指標の基準化 がはかられるのではないかといい，そうでなければ観 察結果が発達の実態にどらつながるかを明らかにする
ことができないであろらと述べた。これに対して今後 さらに着眼点の明確化と基準化をはかりたいと答え た．佐野の研究に続くのが佐々木の高 DQ 児の追跡研 究である.これに対して横山は 1 歳児の $D Q$ の高いも のだけを 3 歳時点でIQ に関係づけようとする意図は どこにあるのか,さらに 1 歳低 $\mathrm{DQ}$ 児は 3 歳時での IQ とどら関係するであろらかとの疑問を投げた。佐々木 の共同研究者である佐野は，だから $\mathrm{DQ}$ と IQ とが本 質的にどうつながるかについて討議してほしいと求め ているだけで，乳児の DQ によって将来への発展が予 測できるなら，学童期に怙ける優秀児への連続に関し て何らかの示唆を求めることがでさようと考えての研 究であり，これだけで断定的結論を出そうとしている のではない.ひとつのアプローチとして研究のいとぐ ちを求めているのだと述べた. 意見を求められて山根 は DQ 算定基準に用いられた既製検査の検査項目を, 環境条件の変化のはげしい現在の乳児にそのままあて はめてよいであろらか, 乳児の生活行動として観察さ れたものが，現在においても発達現象の本質を示する のとして認めてよいという保証がない限り，DQの大 きさへの信頼性は承認されがたいと主張した。この意 見と同様に横山も本質的にどらつながるかが不明な $\mathrm{DQ}$ と IQ の大きさの相関を求めても無意味ではない かと疑問をさしはさんだ. $\mathrm{DQ}$ といら大きさが発達と いう事実にどう関連するかは暫く問わないで, 表面的 に相関係数を計算して低い相関しか得られないなら， $\mathrm{DQ}$ と $\mathrm{IQ}$ との無関係を示するのとうけとれば, その計 算にはそれなりの価値があるといえるであろうといら 意見もあった。

玉川の乳幼児の保育内容の研究に関してその研究の 重要性はいらまでもないが，本報告だけでは未だ改善 への提言とまではなり得ないであろらとの意見を述べ るものがいた。ささらに研究がすすめられ, 保育内容の 改善に貢献できるものになることが要望された。

次いで滝坂は，モンテッソーリ教育法を実施してい る保育園の幼児の遊び行動を観察して, 3 歳で入所し 1 年経過した 4 歳時においてどのように行動のあり方が 変化したかを一定の観察項目に従って明らかにしょう としている．横山はここに用意された観察すべき行動 項目を通じてモンテッソーリ法の教育効果を特徽的に 浮き彫りすることは困難ではないか，とくに遊び以外 の行動として組み入れている項目により重要な行動が 含まれる危険性のあることを指摘した。

望月の観察学習と模倣反応とに関しては，概念規定 が必ずしも明確でないことがあげられたが，討議はさ らに深くは進展しなかった。 
山根の正常児の運動能力の実態調查について藤巻公 裕（埼玉大学）はこうした測定法においては，それぞ れの教育機関の教育担当者に実施してもらった場合そ の測定結果は信頼しにくい. 平均値を出してもズレが 大きくなる技それがあるものだが，この場合はどうか， さらに準備運動をさせたかどうかも影響をおよぼすが どう好置したかとの発言があり，それに答えて本研究 ではくわしい実施要領を規定し，それに笅重に従うこ とを要請し，とくに準備運動はさせず遊びの中で検査 してもらったといい,このような大数調査の場合ある 程度の誤差はさけられないであろらともいう.

\section{発}

座長高 橋 恵子・西 平直 喜

291 青年期の精神健康に関する一考察

一個性化過程と欲求充足, 4 事例の検討を通し て一

292 人種意識の国際比較

名古屋学院大学 生 越 達 美

一八ワイ日系人と日本人一

上智大学 大 迫 俊 夫

293 女子青年における依存の発達

一アメリカ人女子学生の場合一

国立音楽大学 高 橋 恵子

294 下宿通学高校生の精神衛生的調查 (VIII)

一青年期の依存性と自己像一

弘前大学養護教諭養成所 早川三野雄

295 文章完成法による自己概念の分析 III

一中学生の場合一

慶応義塾大学 杉 浦 喜久代

296 対人的認知構造の研究 (11)

一青年における自己概念の変化（その 2)-

$$
\text { 埼玉大学 藤 原 }
$$

297 青年期の自己概念に関する研究（1）

一自己受容性の年龄的変容について一

名古屋大学 宮 沢 秀 次

298 青年心理学に伝記分析的手法を導入する試み

(その 3)

主題分析的手法一

299 大学生に打ける道徳的判断

山梨大学 西 平 直 喜

新潟大学 大西 文 行
最後に末利の運動調整力の指標としての跳下緩衝能 の発達については藤巻から相関係数のよみ方について の質問があり, 藤原正光（都立大）からは 12 歳児と年 長児との緩衝能の差については $\mathrm{t}$ 検定でなく，チュー キー法もしくはライアン法がより適確な検定ができる のではないかとの疑問が出され，久保玄次（都立高保 院）からは緩衝能は運動調整力のらちどのような能力 因子と関連するであろらかと問題提起があったが，そ れらは今後の研究成果にまつことになった。

（山根 薰）
300 評価刺激に対する言語反応の発達的研究

福島大学柴田

291 の研究に対しては, 欲求充足質問紙を用いて精 神的健康をみようとしているが，これでは，欲求の考 え方が並列的ではないか, Maslow の考えたのは, もっ と階層的なものであったはずであるし，精神的健康と いらからは，価值に対する欲求を見逃すわけにはいか ないのではないかという点が上田（姫路工大）によっ て指摘された.これに対して生越は, 考えてはいるが, 質問紙ではでにくいと思うとした。 また，古澤（日女 大）は，個別化と同一化を同じょらに考えて研究がす すめられている点を問題にした，古澤によれば，各対 象との同一化が結合された結果として，個性が出てく ると考えるべきで，また，そのような使い方が一般に はなされていると思うとした。

292 の研究に対しては，まず，人種意識を測定した方 法そのものに対する疑問が, 松尾（福岡教大）らによっ て出された．刺激図版として日本人男女の写真のみを 用いていることじたいが，結果を大きく左右している ことが考えられるので，結論が早く下されすぎている のではないかというものであった。これに対して大迫 は，その種の誤りは "測定誤差” の範囲のものだとし た。ま，岩田（徳島大）が, 人種意識は, 日系八ワ イ人の特性によって変るであろらとしたのに対し，彼 らは三世であり, 現在の住居地域などは八ワイ大学生 であること以上には明らかでないとされた。

293 の研究に対しては, 浜畑 (中部女子大), 生越 (名 古屋学院）が，依存から自立への “発達的変容” のプ 口セスがどのようなものであるかを問題にし，自立を 
どのように測定して，理論化しているかを質した。 こ れに対して高橋は, 依存の変容一一依存の対象の拡大, 対象間の役割分化の明確化, 依存の様式の変化一一 とおしての自立を考㝋てはいるが，今のところは自立 そのものを測定してはいないとした。 また，依存と土 居健郎氏のいらところの甘えとの羑異が，生越によっ て問われた，高橋は，依存を日本人に特有のものとし て限定していないこと, 依存の概念の中に少しも否定 的，あるいは病的なニュアンスを含めないこと，依存 の成長に伴なら質的变化を考えるべきだとしているこ と、などが土居理論との相違だとした。 また，西平（山 梨大）は，彼がモラトリアムを用いて分析していくな かでみるよらなナーシシズムと結びついて自我形成に プラスに働くような不信感が，依存とどのような関係 にあると思うかと質した，高橋は，この研究は現在の ところ人間関係のみに限定していること, しかし，そ の範囲で考えてみると，面接調査で人間不信を訴えた 女子高校生の場合，依存の測定をしてみたところ，依 存要求がどの対象に対しても0 点に近いほど低く, 問 題だと思ったことがあった程度しか資料はないとし た.

295 杉浦喜久代は「文章完成法による自己概念の分 析」の三段として, self-esteem 得点と S-C-T とソシ オメトリック・テストの相互関係を報告, $\mathrm{SE}$ 得点の 高低々回答態度 - 反動他者評面 - 自己内基準 - 表現姿 勢を5つのタイプとして結果を整理した. 福島大の柴 田から、ソシオメトリック・テストで「排斥」をとり あげることによってより豊かな結果を期待できないか といら発言があった。

296 藤原哲は既に 11 回にわたり対人認知構造の研 究を進め, 前回にひき続き, 自己概念と構成概念関係 強度といら観点から検討. これを構成概念の階層的位 置として, 構成概念の統率度と, 従属度を算定, 一方, 構成概念統率度と自己概念変化抵抗として, 自己概念 変化の困難度を調へ，更に，構成概念従属度と自己概 念変化抵抗の関連をみると, 有意な連関が認められた と報告.（297 は発表取消） 298 西平直喜は, 「青年心理
学に伝記分析的手法を導入する試み」の三段として, 主題分析法を紹介，テーマとして「モラトリウム」と 「ナーシシズム」について，既に納得されている概念 を伝記資料と対応させて (説得)，そこからより深い構 造をとりあげよう（会得）とする. この報告に対し， 学芸大福富から、「モラトリウム」と伝記資料の説明を 求め, 西平は,「アイデンティティなき成功」といら考 え方を, B.ショー, やュンラッドの例で説明, 姫路工 業大学の上田は, 類型的把握なのか, また人間の可能 としての自己実現として資料を見たらどうかといら質 問と意見があり，報告者は，できれは類型としてはと らえたくない，むしろ自己選択的な志向としてとらえ たいと思っており，研究の一段階として類型的に分け ている. 自己実現過程としてとらえることは是非進め たいと答えた。

299 大西文行は, 「大学生に怙ける道徳的判断」を報 告. Kohlberg の検查法による 8 つの situation 設定下 での判断を求め, 前因習的水準・因習的水準・後因習 的一原理的水準と6つの stage とによって結果を整理 した. 慶応大の杉浦から，「結果の中に situationごと に異なった stage を使用するものが，男子 $12 \%$ ，女子 4\%であったことについて, 男女差にいみがあるか, ま た situation ごとに stage が異なるとは異様に思わな いか」との質問があり，大西から，統計的処理ではな いから，大していみはない。試験的な試みで，な打十 分検討するとの答があった.

300 最後に柴田葶は「評価刺激に対する言語反応の 発達的研究」を発表, 他者優位評価・自己劣位評価 他者劣位評価・自己優位評価の 4 場面につき, 略画式 事態完成法を用いて調査した。この結果を自己反応・ 他者反応に 2 分しまとめ, 十反応一反応の分布をとり, 1 つの発達心理学のアプローチ法を開拓しようと努め た. 以上のように，これら研究はいずれも青年を研究 対象としたものであり, 教育的効果や自己実現への可 能性や倫理的な社会的好ましさなどを含んだ質疑がか わされた.

（高橋恵子・西平直喜）

\section{発達（301～308）}

座長松田文子・石川尚子

301 Dichotic Listening 法による母音と子音の弁別 北海道教育大学函館分校 青 木 剛士
302 児童と成人の時間評価に及ぼす速度評価の効果

千葉市松田文子 千葉大学松田伯 彦 
303 複雑図形の照合適正時間と図形の回転に依る順 応性

\section{室花工業大学 馬 場 雄 二}

304 「順序」の知覚の発達的検討

一継時呈示刺激の再生をとおして一

京都大学 荒 木 穗 積

305 ミショットの因果関係知覚の発達的研究

日本大学 中 村

306 あいまい図形の認知過程に関する研究 (2)

一ロールシャッハカードへの先行呈示効果につ

いて（瞬間呈示法による）一

京都大学 松川 順子

307 あいまい図形の認知における眼球運動 (その 1)

一分類法の一試み一

日本女子体育大学 石川 尚子

308 あいまい図形の認知における眼球運動 (その 2)

一結果の分析一

$$
\text { 御殿場コロニー 牛島めぐみ }
$$

\section{I 発表と討論の経過}

このセクションの発表は内容がまちまちでまとめる ことができなかったので，個々について質疑および討 論を行った.

301 (青木ほか) の報告は, 日本語の母音と子音が左 右どちらの耳で優位に同定されるかによって大脳半球 の片側優位性を調べょとしたもので, ·今回は子音だ けの報告であったが，子音は右耳優位の傾向にあり， 特に 1 つの語音特性だけが異なる時にその傾向がはっ きりすると述べた。

これに対して, 坂野（京大）より, 再生順を指示し たか,つまりどちらの耳の刺激を先に報告させるかは 条件に入れなかこたのか, 結果の解釈の中に attention p preference の要因は含まれていないかの質疑があ り, preferenceについては考えていなかったこと，し たがって再生順は条件に入れなかったことが答えられ た. 利手との関係の質問には, 左利きは 1 人しかいず, その関係はみていないことが，また，馬場（室蔽工大） のこの方法は幼児に有効かの質問に対しては，母音・ 子音の区別が曖昧な年龄まで下げることによって，母 音・子音の認知の発達を大脳半球の優位性の関係を調 ベてみたいとの考えが述べられた.

302(松田)は, 時空相対現象におけるタウ効果とカッ パー効果の発達的様相を, 静止刺激の継時的点隇事態 によって調へ，速度評価を手がかりとしやすいセット のできた者はアンティ・カッパー効果を示す結果を得 たことによって, 時空相対現象が cue selection sets 仮
説に従っている可能性を示した.

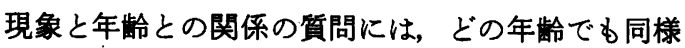
の傾向が見られるとの説明があり, 速度評価の実験と しては無理がないかとの意見には，これは時間評価の 実験であって，速度は手がかりにすぎないとの答が あった.

303 (馬場) は, 無意味で複雑な図形の一部を変えて 異同判断をさせる時，位置を回転し，一定の呈示時間 下で，時間間隔だけを変えたところ，適正呈示時間間 隔は 5 秒であり, 回転図ははじめは難しいが順応が起 ると述べた。

刺激図形の認知度はどらだったかの質問に対して, 複雑さということで図形を定義しただけで認知度につ いて調べていないとの答があった。

304 (荒木) は, 正方形様, または菱形様に配置され た 5 個のランプの継時的呈示後にランプの位置と順序 を再生させる実験を行い, 場所の再生は 2 次元形成期 に既に可能であるが, 順序知覚は 3 次元形成期で可能 になる結果を得たことによって, 順序知覚が 4 歳後半 から 5 歳頃のいわゆる発達の質的転換期に獲得される と述べた。

石川（日女体）から, 位直の再生を並列的操作, 順 序の再生を系列的操作と考えているのかとの質問があ り，そう考えたいと答えた。野村（京教大）から，順 序は再生テストだが場所の方は既に座標が子どもの中 にあって一種の再認テストになっているために, 再生 率に差が出たのではないかという疑問が出され, 確か に場所ができないと順序もできないといら課題のまず さはあるが，全体的にみれば発達の違いが両者に現れ るのではないかと答えた. 眼球運動のとり方について の質問には，刺激と眼球運動のテープを同時にミキシ ングする方法をとっているとの説明があった. 眼球運 動では停留回数よりは停留にいたる動きが重要ではな いかとか,リハーサルのような順序記憶のストラテ ジーは関与していないかという質疑には, それぞれ チェックあるいは注意しているということであった。

305 (中村) は, 幼児期の因果関係の知覚の様相をミ ショット現象によって実験し, 衝突印象の生起率とそ の原因を接近していく方の物体に認める傾向とが年齢 とともに増すといら結果から，ミショット現象の 3 局 面を個々に直観的に捉える傾向から，3局面を1つの ゲシタルトとして統合する方向へと発展すると述へ た。

質疑は，何が見えたかという質問で年少児が認知し たことを報告できるだろらか。年龄によって質問の受 け取り方に違いはないか。知覚・印象・判断の区別は 
できるか, 内省心理学的になる危険はないか、どこか でチェックした方がよいのではないか，といった点に 集中した。 中村は, 年少児の反応を言語報告だけでみ るのは不十分かもしれないが，報告内容を知覚内容と して分析するよりしかたないし，質問の受け取り方の 年齢差をチェックするいい方法も思いつかないと答え た. 因果反応がどの発達段階で現われるかについては, この実験ではわからないが，ミショットは生得的と考 えているとの説明があり，4〜6歳間の明白な男女差の 理由については，わからないということであった。な お，男女差を連続量のように取ったグラフは問題であ るとの指摘があった。

306 (松川）は，ロールシャッハカードの認知に呈示 時間がどう影響するか。各カードに意味づけされやす い概念を含む図形を先行提示するとどうなるかを調 ベ, 呈示時間が, $12 \mathrm{msec} よ り 103 \mathrm{msec}$ の方が反応 しやすく，動物・人間反応が多くなること．先行図形 があるとその方向にカードを認知しやすくなり, 潜時 は長く，不反応が増すこと．カードが暧昧なほど先行 四形の効果が大きいことなどを述べた。

307 (石川), 308 (牛島) は, 円や三角形などの単純 四形 12 種類にメッシュ化ノイズをかけて㖟昧にし, も との図を認知するまでの眼球運動を記録分析すること によって図形認知のための視覚的探索活動の特徵を捉 えようとしたもので, その 1 では, 注視点の移動が図 形全体に渡るか, 部分的か, 答は正か否か, 判断の手 がかりをどこに求めているかなどからの認知反応の分
類がなされ，その 2 では, ノイズが多くて暧昧なほど 全体反応や誤反応が多く，潜時も長いが，ノイズが減 ると部分反応になり，ついには 1 点反応つまり完全視 野反応になることなどを報告した。

これに対して，馬場（室苚工大）から，幼児では， 簡単な四形への反応より，もっと複雑な図形処理が問 題なのではないかという意見が出され，図形の認知が どういら内的プロセスによるのかを，たとえば注視点 から探っていくことに意味はあると考えているとの考 えが述べられた。

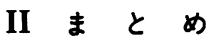

各発表は，それなりの実験成果を報告しており，苦 心のあとが見られるが，全体的に，今後もらひと努力 がほしいといら感じもあった.

今回, 301，302，304，305 の各研究を通して共通に 出てきたのは, 反応のチェックの必要性と難しさであ る.たとえば，301では片耳に優位な結果に含まれる preferenceのような要因のコントロールのしかた, 302 では子どもに速度評価と時間評価を区別させる方 法, 304 では再生テストにおける再認要因のチェック のしかた，305 では幼児における言語反応以外の知覚 内容のとり方，などである，303，306，307，308は， この先どらいら方向にすすめていくかが課題といえる かもしれない。

（石川尚子・松田文子）

\begin{abstract}
発
座長岡山禧子・坂本幸

一被服語異使用の実態 $2 \cdot 3 \cdot 4$ 歳児の場合

東大阪短期大学 岡山禧子

一母子場面におけるスピーチサンプル時間の検
\end{abstract}

309 母と子の対話における「コトバ」の機能 第 6 報

310 言語発達観察法に関する研究 討一

東京学芸大学 飯 高 京子

3116 歳児の言語的カテゴリー概念 ○山田寿子

$(309 \sim 316)$

313 Decoding Ability の発達

近幾大学 浜 崎 幸 夫 " ○登 根 健之助 扣茶の水女子大学坂田尚美 314 乳幼児の言語発達に関する調査研究 [III] 仙台市精神衛生相談所 前 田 紀代子 315 ろら児の身振り言語一手話による叙述と理解 (1)

$\begin{array}{crrrr}\text { 東北大学 } & \text { ○吉 } & \text { 武 } & \text { 清 } & \text { 美 } \\ \prime \prime & \text { 坂 } & \text { 本 } & \text { 幸 }\end{array}$

316 ろう児の身振り言語一手話による叙述と理解

名古屋女子大学 湯 川 隆 子

312 園児に対するひらがな文字の一斉指導法（4）

$\begin{array}{crrr}\text { 東北大学 } & \text { ○坂 } & \text { 本 } & \text { 幸 } \\ \prime \prime & \text { 吉 } & \text { 武 清 } & \text { 美 }\end{array}$ 


\section{発表と討論の経過}

この部会の発表は，幼児の言語発達の様相を探ろら とする意味では共通であるが，各研究の内容はそれぞ れ視点を異にし，目的，方法も多角的で千差万別の感 があった，従って質疑は方法，結果などの具体的事実 に集中し，共通の課題への示唆を得るには時間不足で 至り得なかった，発表内容別プログラム編成の困難さ を痛感した。討論は発表内容によって，比較的自然な 場面での発話に関するものと, 一定の設問や言語的課 題を設定して，その反応語や理解能力などを調べよう とするものと 2 群に大別して実施したが，312 は文字 指導法の試みであり，315，316 は対象がろう母子とい ら特異なむのであったので次に各発表順に発表と質疑 の概念の概要を記す（質疑・意見を $\mathrm{Q}$ ：回答を $\mathrm{A}$ ：と して記す).

309 母と子の家庭での自然な対話集録資料に基づき, 母子関係を考慮しつつ幼児の言語発達過程を調べ，今 回は被服語彙を中心に語䱊数, 使用回数の各年龄群別 傾向や食物語との比較などについて報告. Q：(鈴木 女子聖学院短大） 2 藏児の「はきもの」に関する使用回 数が多いことの意味づけと個人差について. A :「はき もの」の自立状態, 遊びの継続時間, 他項目語の使用 量などと関係があるよらだが，個人差はたしかに大き い. Q:（飯高 東学大）指示代名詞（こ，そ，あ，ど） の使用について調べると興味深いと思う. A : 示唆を 感謝する. 試みてみたい.

310 幼児の言語発達研究資料として適切な発話廿 ンプルを得る観察時間を検討し, 週 1 回 30 分ずつ 10 週分の母子自由遊び場面の録画, 録亲:を実施し, 15 分 間より 30 分間の方が偏向が少なく望ましいと報告. Q :(岩立 都立大) 自由発話場面での母親の統制をどう 考えるか,サンプル採取の間隔はどのくらいが適切か。 A：母親は共同研究者の飯高自身であり, 統制に問題 はなかった。 サンプル間隔は研究目的によって当然異 なるはずだ.

3116 歳園児に上位概念（食べ物，乗り物など）を 教示し, 想起された下位概念のカテゴリーを調べたも ので, 反応語の量や質の傾向について報告. Q：(日下 東北大）教示された語のカテゴリー獲得レベルは同一 かどらか。また自由再生法よりも再認法による方が子 どもの概念の獲得状況をよく把握できるのではない か. A : 必ずしも同一とは限らない. 児童の記憶容量調 查が目的なので, 子どもの自然なカテゴリ一限界をみ るには，選択しなければならないといら制約がないの で自由再生法を採った。 自由再生法と再認法の対比的
研究をすれば，概念のネットワークなどに関して新し い知見が得られよう。

312 幼児に対する「ひらかな」の一斉指導の可能性 を, 涌出・一字法教材と称する具体的指導法から探索 して報告. Q: (飯高 東学大)この研究の意団するとこ ろは何か, 幼稚園の予備校化に拍車をかける恐れはな いか. A：予備校化などという方向の意四はないが, 利 用される可能性はあり得る， Q: (日下) 文字は一斉指 導でなく, 個々の子どもの内的要求を考慮すべきで, 書くより読むことの方が優先するのではないか. (坂本 東北大）手指機能発達の段階から考えて意味を持つ書 字能力の要求は尚早ではないか，ことばと文字を分離 して 1 字ずつ機械的に教えることは危険ではないか。 A：園児に書字の要求があり, 涌出法は読み書きを同 時に教える方法で, 文字に興味を持たせ, 言葉と結び つけ, 手指運動の発達む期待できるはずである. Q: 石 戸谷（都心障センター）表意文字は表音文字より受容 され易いが，その意味での漢字教材は使用しないか。 $\mathrm{A}$ : 漢字は含まない. 幼児は涌出法に関心を示し, ゲー 么的興味もあるようだ。

1136 歳, 8 歳, 10 歳, 大学生の 4 グループに 6 種 の言語伝達表示 (メッセージ) を聞かせて, 各群の聞 き取り理解能力の発達状態を調へ，幼児の言語伝達の 効率の悪さは, 話し手としてばかりでなく, 聞き手と しての能力が低いことにもよると報告. Q：(岩立) Decoding Ability なる用語は心理学的にどのような 内容として使用されたのか。 また文法などとの関係は どうか. A : 話を聞く能力の中で, メッセージを受容し て判断する過程をDecode と考えた. 文法との関連は 分析していない:Q：(坂本) 2 つのタイプの文のうち, 分析的なものは文も長いのではないか, 長いとすれば, 正反応率の低さは内容と文の長さの両方に関係がある のではないか. A：あるかも知れないので検討する、 Q ：(飯高）聴覚的記銘力（被験児の）は調べたか，A： 調べていない， Q：岡山）メッセージと眓形を示して ほしい, A: 呈示, 説明.

314 発話開始期から 2 藏ごろまでを中心に発話の 変化を発達的にきめこまかく記録し, 般化の分化の過 程について報告. Q：(岩立) 得られた語の分析だけで なく, 統制条件下の調査も必要ではないか, 日常場面 では母の発話との関連が不明で, 分析上問題があるの ではないか，おうむ返しの模倣の処置はどうしたか。 $\mathrm{A}$ : 月 1 回実物やカード提示の調查も実施している. 発達の実態把握には毎日の記録がより優れていると思 う.おうむ返しは印をつけて資料に含めた。 $\mathrm{Q}$ ：(浜名 北大）母親の幼児音, 幼児語への対応はどうだったか. 
$\mathrm{A}$ ：特に留意せず許容し，母親自身も時に使用した. $\mathrm{Q}$ : 小田(都心障センター) 1 歳 4 か月を 2 語文初発の第 1 転機, 1 藏 7 か月を 2 語文増加の第 2 転機と考察した ことについて, 初発の 2 語文の具体例と, 2 つの時期の 2 語文の質的な差は何か. A : 初発 2 語文は「ニイチャ ン ネンネ」, 質的な差については検討の予定である.

315,316 人形, 粘土, ボタン, 鉛筆などを用いた 手話による理解テスト，叙述テストを，ろら母を介し て実施し，ろう児の言語概念伝達に関する問題点を報 告. $\mathrm{Q}$ ：秋広（都立立川ろら）被験児の教育歴, 聴力 損失度, 個人補聴器装用状況について, (小田) 万丂児 の母親の聴力損失度, 書字能力について. A：それぞれ の事実について回答. Q：(鈴木）テスト教示の際の母 親の統制について．A：特にろらの母親なので事前の 統制は困難である．テスト形式を利用した回答場面で の母子の対応観察が目的なので, 教示の統制は直接の
問題とはならない.

\section{I ま と め}

母子場面を扱った発表が $5 つ$ つ, 幼児の言語発達 に果たす母親の役割の大きさが，共通の認識として印 象づけられたが, 各研究の方法や結果についての質疑, 意見に時間をとられ，全体的な研究の方向づけに関す

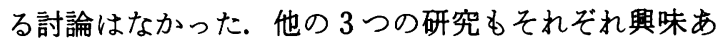
る問題が報告されたが，他の発表との関連はつけ難い まま独自の質疑に終った，今後の言語発達の研究には 縦断的研究と横断的研究, 自然発話場面と実験的場面 の各研究方法について，それぞれの問題点や特徵を改 めて認識し，継続的に相互の情報を交換しながら，よ り効率的な体系を築いていく必要があろう.

（岡山禧子・坂本 幸）

\section{発 \\ 座長 天 羽大平・関岶一}

317 人格と発達の構造

一児童期と成人・老年期の比較検討一

日本福祉大学 金田 利子

318 幼児の性格傾向に関する研究 (IV)

日本女子大学 天 羽大 平

319 発表取消

320 乳児の行動パターンの発達に関する研究一多動 な子

$\begin{array}{ccc}\text { 佼成病院小児保健部 } & \text { 佐 野 } & \text { 良五郎 } \\ \text { " } & \text { ○堤 } & \text { 節 子 } \\ \text { " } & \text { 佐々木 公子 }\end{array}$

321 発表取消

322 集団知能検查における誤答傾向

323 教科に対する興味

324 自己怙よび両親へのイメージ

神戸大学教育学部 $\bigcirc$ 沢 田 瑞 也

\begin{tabular}{|c|c|c|c|}
\hline " & 津 留 & & 苏 \\
\hline " & 富 本 & 佳 & 郎 \\
\hline " & 伊 藤 & 隆 & \\
\hline " & 八重島 & 建 & \\
\hline " & 古 厩 & 勝 & \\
\hline " & ○小 石 & 寛 & \\
\hline$"$ & 虎 田 & 真 & \\
\hline
\end{tabular}

神戸大学教養部 $\bigcirc$ 関 峋 一

滝上凱 令

\section{I 発表と討論}

金田 (317) は現在の発達研究が青年期で終ることを 指摘し, 成年・老年までの一貫した発達の認識が必要 であること及び手段・様式・内容との関連で人格と発 達を構造的に把握するための図式的モデルを示した.

天羽（318）は変化が少なく, 基本的とみられる対外 関心 (対人・対物) と Vitality（興奮・抑制）について 両者とも中程度では 10 年後でも変化がみられないが, 極端な程度では親の性格の方向に変化する可能性の高 いことを示した。

是 (320) は所属病院での乳幼児のうち多動とみられ る幼児を選択, 彼らは多動とみられない乳児に比し産 科的異常, Clothon the face test. 始歩の時期の早期 化, 事故多発の点で有意差があり, 育児不安型の母親 が多いことを報告した。

沢田 (322) は小学校 6 年間の集団式知能検査におけ る誤答率について男子では隣接の学年間相関が比較的 高いが，女子にはそのような一貫性の少ないこと, 誤 答率が一貫して低い児童は高い児童に比し, 知能偏差 値，教科成績ともに高いことなどを報告した。

小石 (323) は沢田と同じ追跡研究の一環として教科 に対する興味を調查し, 男女とも算数・体育は一貫し 
て好みの順位が高く, 社会の女子, 音楽の男子は比較 的好みの順位が低く，また各学年と6 年生との相関俰 数は, 社会以外は学年をおらごとに高くなることなど 好みの学年差, 科目差, 性差を報告した。

関（324）は上記追跡研究の中で自己イメージは一貫 してやや積極的な肯定傾向だが学年の進行とともにわ ずかに肯定値が低下すること，両親イメージへの肯定 的傾向は強く，また異性の親に多少肯定的なこと，父 母イメージの相関は一貫して高いこと，および学年の 進行とともに自己・父母各イメージ間の分化を報告し た.

発表後, 討論に移った.

金田（317）については八幡ゆかり（東京学芸大）, 富本佳郎（神戸大）らから発達の手段・機能，身体之 主導的活動との関連, 価値観をどのように体系に組む か，人格における発達の内容及びそのとらえ方につい ての具体的説明などが求められた，発表者は発表した 人格構造モデルを引用しつつ主導的活動及び価値観の 位置づけを説明し，今後構造論を具体的に検証するた めの研究方向及び方法について意見を表明した。

天羽(318)については関, 富本, 佐々木公子らから発 表論文中の表についての質問, 長期研究では同一の尺 度で測定しても尺度の受けとめ方が年龄で異なり, 各 年齢での測度は異なるのではないか，またVitality と 多動な子との関連などに関し質問が出された。測度に ついてはサンプルの数を十分にそろえ各年龄間の測定 値相関が十分高ければ尺度の受けとめ方は等質, 相関 が低ければ受けとめ方が変化したと洘えるとの意見が 出され，また多動児については脳損傷のケースを除け ば彼らは抑制力が少なく興奮性の高い児童ではないか との説明があった。

堤（320）については金田, 天羽, 関らから胎動にお ける多動, 多動児の定義などについて質問が出された。 これに対し乳児の行動パターンの発達に関する研究が
進行中だがその中に胎動に関する質問項目のあること が述べられた。多動児の定義については脳波検査のよ うな客観的定義は病院での健康診断の場では困難だ が，母親の訴え，診察時所見，MCCテスト場面できわ だって「よく動く子」があり，そのような子を多動な 子と考えた旨の説明があった。

神戸大学の一連の発表（322～324）については縦断 的研究の開始当初における全体的構想, 今後の継続 • 展開の方向, 対象者の価値観の形成の検討の有無など について，金田ほかから質問があった，全体的構想に ついては, 主として共同研究者の富本より，幼児・児 童・生徒のパーソナリティ発達に重要と思われる心理 的行動的諸特性を測定してその発達過程を明らかに し, かつ発達段階ごとにいくつかの特性の関連から パーソナリティの構造理論も検討しようとする構想で 出発したこと,したがって収集した資料は第 13 回総会 の宿題報告に見るように，さまざまな領域にわたって いるが，今回はそのらち部分的に繮まったもの，ある いは従来比較的取り上げられなかったものに限って報 告したと答があった. 今後の展開については, 現在こ の対象者が中学 3 年であるので，さらに若干の資料を 収集しており，これと併せて検討を試みる予定である こと, 対象者の全体的な傾向よりも, 発達的変化の基 本的な類型を導き出すことを考えていること, さらに より将来に向けては参加時期の比較的遅い若い共同研 究者により, 新しい構想での展開も考虑している旨が 答えられた．価値観の形成の検討については，当初の 構想では取り上げたいとしていたが，特に小学校低学 年ではこれを的確に把握する技法が得られず 現在の ところ行われていないといら答であった。 な拉小学校 の低学年では, 自己像の SD 尺度による評定でも重 複・欠落が多く無理な点のあったことが併せ答えられ た。

（天羽大平・関 岶一）

\section{発達（325～331）}

座長伊藤み就荒木紀幸

325 色彩知覚と色彩概念 3

青色系指示色名とそのイメージ

浜松医科大学 佐藤 愛子

326 幼児の二語文習得における.イメージの役割

東京教育大学大学院伊藤みね
327 比較級を含む文の理解における行為と意味との 関係について

328 児童の言語連想の研究 (3)

$$
\text { 東京教育大学 奥 野 正 義 }
$$

（書記連想反応語分類表作成の試み）

宮崎大学教育学部 荒 木 紀 幸

329 幼児における事物操作と言語の関係 
広島大学教育学部 中川 伸子 330 幼児の分類作業における言語の役割観点変換と 発話の分析

大阪市教育研究所 山 本 和 美

331 分類学習に及ぼす訓練効果の発達的変化

広島大学教育学部 寺 尾 容子

\section{I 発表と討論の経過}

発表はほぼ論文集に沿って行われ, 補足説明も加え られたが，それによって基本的に結論が改められたも のもなかったので，ここでは討議内容を紹介すること とする.

佐藤（325）に対して指示色の同定にみられる個人差 の原因について(荒木・宮崎大) (1) 色に関しての概念 構造の存在がなかった, (2) 戦後色相名が使用される ようになり, 従前よりの指示色名をどの程度操作可能 であったか否かの説明があり，色弁別の良さと別に考 えるべきかに対し肯定し，プロセスとして色相名又は 指示色(片方)が片方を補らことがあり得ると答えた. 浜重（荻城大）の使用した指示色と被験者の年代との 間に関連があるのかに対して，死語化したものを省い た戦前からのものであると答えた。

伊藤 (326) について方法上の様々な問題が指摘され た. 北尾（大阪教育大), 新田（東京女大）は二語文学 習の実験手続を, 北尾, 佐藤 (宮崎大), 大石 (東京大) は言語の法則性を, 荒木は幼児の言語構造との関連を 質問したのに対し，実験操作上の言語法則であり，言 語構造である旨の説明がなされた。佐藤（宮崎大）の イメージの媒介効果とは何かに対し, 実験群で単語と 図形を対応させた結果それらの学習が優れたことであ ると答えた. 熟知語で差がみられない点の解釈につい て, ことば自体にイメージがあり, 連合学習と規則学 習の発達時期に不一致があるためと答えた. 新田より イメージを伴なった条件で B・A 順の誤った再生をす る $\mathrm{S}_{\boldsymbol{s}}$ 数が少ないか, その場合にはイメージをつける必 要があるのではないかとの示唆に対し, まだ分析して いないが今後検討するとの答があった。

奥野 (327) について解积上の問題が指摘された。 大 石より, 課題遂行に際し教示を自らの行為のプログラ ムに変換する必要があろう. 従って教示文と知覚事態 の構造的関係でなく, 教示文と知覚事態を与えて出て きた行為ブログラムの構造的関係の研究でないかとの 疑問が提出された，佐藤（浜松医大）は文章理解がな くても知覚上でマッチングできるので, 知覚上カゥン ターバランスする必要がある点を指摘した. 神園（筑 波大）の大小の判定基準に対する質疑に対しデータ上
の問題はなかった旨り解答があった.

荒木（328）について佐藤（浜医大）の反応般化の観 点から言語習慣の強度をみてよいのかの問に対し, 反 応般化といらより児童がこれまでに獲得してきた語菓 のポテンシャリティーの強度と考えた方がよいとの解 答があった。 また地域による語彙の比較を行っている かに対し宮崎県避地との比較を行らためデータを収集 しているとの答があった。

中川（329）に関して前田（東京教育大）ょり言語と 事物操作との関係を知るためには本研究の発達測度は 単なる相関的なものに過ぎず, 認知構造を反映した測 度をとる必要があろらとの問題提示や, 荒木の課題を $4 つ に$ 分けた意図は何かに対して語と語の結合を言語 の構造特性と考え, それと形式的操作の組み合せの対 応といら中で検討したと解答した。 そのような対応関 係を扱ら場合でも言語教示及び課題遂行のために使用 される言語活動がある（山崎・東京教育大）と思われ るが，に対し，言語と事物操作に直接的な相互作用が ないと考えると答えた。

山本（330）に対して, 浜重がいくつか質問をした. 後片づけの時の発話について, 分析の対象としていな い, 観点変換と発話の関連については分類作業と自由 遊びで材料が同じであり, 思考のつながりが自由遊び の中に見出せた, 能力が増すにつれ社会的発話の回数 が増加するのか対して, 結果的にそうであり, 思考 と関連した言葉が社会的発話の中に入ってくるとの解 答があった. 山崎の観点変換の持つ特性のみで測定す るだけでよいかに対して,迷いながら使用しているが， 幼児の思考の中で観点変換が重要であるといら予想の 中で検討していると答えた.

寺尾 (331) に対して, 新田の事例の等価性について, 概念の意味がわかっているかどうかでなく, 概念名, ラベルが知っているかであると答えた. 前田の未知の 概念を使用すべきであるとの問に対して無意味緅等で は子どもの理解を越えるし，末知であると知っている， いないの効果が入り不適当と答えた. 概念行動の研究 といら点から概念ラベルでなく内容を扱らべきである との疑念に対し，幼児は材料の一部に注目して反応す るので問題が残ると答えた。崎より言語ラベルが媒 介として働いたとあるが，何が何をラべルしがの 問に対し，例えば，イチゴの次元にくだものといらラ ベルをしたと答えた。

\section{II ま と め}

この部屋の発表は言語, 教示, 概念と操作（定位・ 事物操作・分類）の関連を扱ったものと語彙に関する 
ものに分けることができる、いずれの研究す教育実践 のための基礎実験であり, 調査であり, それ相当の価 値が認められるが，討論を通じて指摘された如く，実 験計画，方法，概念の規定が概して緻密さを欠き，再
考する必要があるように思われた。ともあれ，27名の 会員が積極的に討論に加わり，盛況の内に終了したこ とを感謝する.

（荒木紀幸・伊藤みね）
発

座長 石川透・椋 野

332 青年期に扣ける親子関係（その 6)

一親に対する態度と対話一

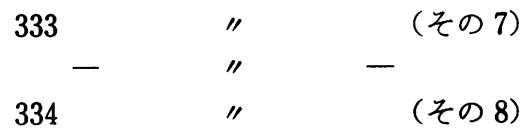

一親子間の対話一

$\begin{array}{crrrr}\text { 愛知学院大学 } & \text { 大 } & \text { 西 } & \text { 誠一郎 } \\ \prime \prime & \text { 酒 } & \text { 井 } & \text { 亮 } & \text { 爾 } \\ \prime \prime & \text { 千 } & \text { 野 } & \text { 直 } & \text { 二 } \\ \text { 愛知教育大学 } & \text { 武 } & \text { 上 } & \text { 薰 } \\ \text { 名古屋大学 } & \text { 久 } & \text { 世 } & \text { 敏 } & \text { 雄 } \\ \text { 名古屋女子大学 } & \text { 三 輪 } & \text { 弘 } & \text { 道 } \\ \prime \prime & \text { (6)平 } & \text { 林 } & & \text { 進 } \\ \text { 静岡大学 } & \text { (7)石 } & \text { 川 } & \text { 透 } \\ \text { " } & \text { 田 } & \text { 中 } & \text { 鉄 } & \text { 也 } \\ \text { 岐阜大学 } & \text { 返 } & \text { 田 } & & \text { 健 } \\ \text { 三重大学 } & \text { 戸 } & \text { 田 } & & \text { 晋 }\end{array}$

南陽高等学校 (8)三 宅 正 夫

335 コミュニケーションにおける母親からの

Touch の意味について

一中学生の場合一

336 短大生の興味の研究

日本大学 蓮 見 将 敏

今治明徳短期大学 ○椋 野 要

岡山県立短期大学 松 田 淳之助

就実短期大学 笹 野 完 二

337 青年期感傷性の研究 (II)

中国短期大学 平 松 芳 樹

一年齢的変化とその時代的変動 (2)一

東京学芸大学 五 味 義 夫

338 日本の児童の感情の研究

一その 1-

$\begin{array}{rllll}\text { 小田原女子短期大学 } & \text { 児 } & & & \text { 省 } \\ \text { 東京家政大学 } & \text { 阿 } & \text { 部 } & \text { 明 } \\ \text { 星美短期大学 } & \text { 加 } & \text { 古 } & \text { 明 } & \end{array}$
東京成徳短期大学 ○中 田 カョ子 339 子供は年齢をどう価値づけているか

富山大学 塚 野 州一

\section{I 全体的特徽}

参会者約 50 名，発表者が多いため残り時間が少な く,十分な討論ができなかった. 研究題目は種々異なっ たが，338，339 は児童期，その他は青年期に関係する 発表内容であった点で, 討論者の間に共通の係留点が あり, 討論は比較的活発に行われた.

討論が多かった話題は, 332-334の3つの発表で あった. 平林はサーストンの等現間隔法を使って親に 対する態度測定尺度を作り，石川はそれで測定した大 学生の態度と親子間の対話頻度の関係, 三宅は高校生 の対話要求と現実の対話頻度などの関係を述べた．親 子の断絶はジャーナリズムで誇張され過ぎた、(コン ガー，青年と若年，1973）観がないではないが，それ と親子の対話の関係は色々調査されているけれども, な技心理学的に突込んだ研究が望まれることが，討論 の刺激となったのであろう.

337 (五味) の青年の感傷性が $\mathrm{S}$ (悲哀)/H（爽快） で定義された点は面白いと評価されたが，この数量化 についていろいろ論議があった。 また，335（蓮見）の 中学生が身体を母からタッチされた時の意味内容, 336 （椋野）の興味の発達的様相, 338 (中田）の児童の感 情発達などについても，若干の質疑と討論があった。

\section{II 討論の内容}

松尾（福岡教大）は態度得点の算出法を問い，平林 は○をつけた項目番号を得点とし，その合計点を選択 項目数で割ると答えた. 蓮見（日大）は対話の程度を 4 段階にした理由を質し，どちらでもない（普通）が あってもよいのではないかと述べたのに対し，石川は 前の研究で検討した結果, これで判定できるとわかっ たから引続き使ったと答えた。

・野口（明治学院大）は, 親と話合いをしているか, いないかの質問では，単に頭が痛いと親に告げるよう 
な場合は含まれず，健康そのものについて話し合う時 のみが含まれるのかどらか, 被調査者に「話合い」の 意味が理解されないのではないか，また，話合いたい が,この話題は親には無理だと判断して止めるように, 両親像により対話は異なるのではないかと質し，石川 はそれは対話成立の要件として色々聴かして欲しいと 望んだ. 椋野 (今治明徳短大)「そらいら点, 前日の対 話内容を毎日つける対話の統制日記を何日か続けさす 方法はどうか」石川対話を録音することなど話し合っ た事があるが，な検討の余地がある」と答えた。平 尾（都立教研）は, (2) 対話の項目を日常生活, 人生将 来, 悩みに分けた理由, (2) 悩みの種類により父と母と に対する対話は異なるのではないかと尋ね, 三宅は,

(1) 従来の調查結果から目立つものを選んだ, (2) 悩み の詳細については未だ十分調べてはない，と答えた。

児玉（小田原女子短大）は, 感傷性の定義はどうか と質し，五味は本質はあいまいな感情で，その構造は 例えば時間的には過去の回想と未来へのあこがれを含 むよらに，アンビバレントなものと考えるが，一応 S/ $\mathrm{H}$ と定義した. 児玉 $「 \mathrm{~S} / \mathrm{H}$ は面白いが $\mathrm{R}$ はどちらかに 移らないか， $\mathrm{S} /(\mathrm{H}+\mathrm{R})$ としたらどらか」五味「従来 の結果と比較するため $\mathrm{S} / \mathrm{H}$ としたが, もっと検討した い」千野（愛知学院大）は表 3 の様な単調関係なら S で示されないかと質した．H との関係で事態は変るの で $\mathrm{S} / \mathrm{H}$ としたが, $\mathrm{R}$ は時代と共に次第に増すから問題
であるとの答. 関（神戸大）は個人の $\mathrm{S} / \mathrm{H}$ の分布はど らか, そのピークは各年代とも初潮開始年齢のピーク より約 1 年遅れているが, 初潮の若年化と関係はない かと質し，集団としての数値しか出していないか，今 後個人の感傷度も出してみたいと答えた. 椋野は, 五 味が発達加速現象と見ているようだが，身体の加速現 象は認められているが, 精神の方は未決定である, 加 速現象は時間上の変化であって, 社会といら空間の変 化が時代により与える影響が異なることが考えられ， それが的確におさえられない以上，加速現象といえな いと外国の研究により述べた。

小宮山（科学警察研）は恐怖の対象に災害の頻度が 高いのは, 調査時に何か事故があったのではないかと 問い, 中田はそれは無かったと答え, 児玉は死は最近, 子どもの早期に現われる傾向があり，単に言葉だけの 問題かどらか問題であると述べた，小宮山「低年齢の 子どもの感情に一貫性があるか」中田「現在，母親に 幼児の観察をしてもらっているので，その結果とつき 合わせたい」. 藤原（東学大）は被調查者の地域分布を 尋ね，都内の色々な地区から選んだとの答．また藤原 は一般に数量化は対象の性質を明らかにした上で行う べきた， S/H では記述尺度で表わすことも必要ではな いかと論じた。 まだ貴重な意見もあったようだが，時 間切れで終った。

（石川 透・椋野 要）
発 達（340～345）

340 女性の生活史に関する研究 II

-1. 職経験を中心とする生活歴の類型一

弘前大学 (3)福 井 とみ子
文教大学 (6)本 田 時 雄

$341-2$. 職業経歴の要因分析一

$342-3$. 恋愛と結婚一

筑波大学 (2)伊 藤 裕 子

東京都立大学 (3)川 浦 康 至

$343-4$. 子に対する価値感一

県立新潟女子短期大学 (5)田 代 俊子

$344-5$. 生活の広がりと子への期待一 山梨県立女子短期大学 (1)田 中 政子

$345-6$. 母-娘のペアによる比較一

東京教育大学 山 村 香 苗

\section{I 発表と討論の要旨}

本分科会の発表は，昨年にひき続いた同一テーマに よる一連のもので，補足資料を用いながら行われた.

発表 340３44 は, 同一のデータを, 世代を中心とし て分析した研究であり, 発表 345 は母・娘のペア・ データを用い，構造化を志向したものである．それら の要旨は次のようであった。

340 (田中)：世代区分は教育制度を参考にして行わ れたが, 今回は「大正生れ(T)」,「昭和 1 析生れ(S1)」 および「昭和 2 析生れ（S2)」の 3 世代を用いた。 その 3 世代を娘一妻（結婚）一母 (出産) の 3 時期における 5 種の職経験のパターンとの関係について分析した. 3 世代で有職率が変化し，さらに昭和の 2 世代では， フ ルタイム勤務群とその他の群と差異が夫の年収, 妻の 生活費負担, 就業および家事・育児に関する意見と子 
どもに対する価値観において認められた.

341 (伊藤)：フルタイム勤務群と職歴皆無群を弁別 する要因を求めて, 数量化 II 類を用いた. 有職群は若 い世代, 高学歴, 夫の低学歴・低年収および家事協力 有, 娘に対する有職希望などと関係が強く, 女性の職 経歴には時代的要因, 学歴, 結婚相手の備えている条 件などが影響していた。

342 (川浦)：恋愛，結婚および性について，世代間 の比較を行った. 若い世代は, 古い世代に比して, 上 記 3 項目に関する意識や行動が著しく变化していた が，他方伝統主義的なものも挙式のような所に現われ ていた。 また，結婚相手の条件に関して, Schaie, K.W. のモデルを適用し，時代や年齢の影響を抽出した.

343 (福井)：女性が子どもをどのように位置づけて いるかを,因子分析によって分析した. 抽出された 5 因 子は, (1) 社会的規範, (2) 生き甲斐, (3) 自己の分身, (4) 枷，(5) 独立した存在であった. その因子得点によ る分析で, 学歴, 世代, キャリア・バターン, 第 $1 子$ 出産時の問題などに関して, 既婚, 未婚毎に, またそ の両者間に 5 因子のパターンの差異が認められた.

344 (田代)：女性の生活の広がり（社会的活動への 参加・関心, 職業生活）と子への期待とを分析して, 世代間に差のあったものとないものとを見出した．生 活空間の広がり大, 子どもの高学歴および学歴の性差 無などが未婚者に多いが，子どもにしつけたいことな どには世代差がないまたずっと有職で, 社会的関心 の広い母親や職業生活を続けたいと思っている未婚女 性は，子に対して長く有職であることを期待し，教育・ しつけなどの点で性による区別を考えていなかった。

345(本田)：母・娘のペア・データを用いて，(1) 結 婚相手の条件, (2) 結婚生活に括ける性のイメージに 関して, (a) 家 (庭), (b) 個人, (C) 年齢, (d) 時代の 4 要因を仮定し，(2)では時代の影锌が弱く，年龄の要因 が強く作用していた。 また (1)に関しては，個人の要因 の影響が大きかった.
討論：発表者以外の参加者が目（北教大) と劉(大 教大, 台湾の留学生) しかいなかったので, 討論は情 報交換をまじえて活発に行われた。要点は次のようで あった。

1. サンプルについて；片寄りのない，ランダムな サンプルによる normative study が最も望ましいが, 特性がコントロールされたサンプルによる研究の積み 重ねも価値があり，そしてより現実的であろう。

2. 回想法および予想 (希望) 法の適用について; 本来，これらの技法を用いずに，縦断的研究が望まし いが，現実としてはかなり困難である（児童期までの 研究が殆どである)。児童期までは，回想法や予想法は その信頼性に疑問が残るが，青年期以後では（特に， 自我関与が大きい事柄について), 回想や予想はかなり 信頼し得るだろう。この点について, 発表者側から, 「来年から 100 200 名の follow up によって, 信頼性 を確かめたい」との発言があった。

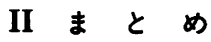

「生活史」という耳馴れないテーマのためか, または 若干グループの単独発表のためか, 参加者は前記のと おり少なかったが，非常に熱心だった。

「生活史」の研究は, Schaie, K.W.のモデルの時間 軸に回想掞よび予想を挿入した技法を用いて，生活の 流れの中で人間をとらえようとするすのである。.そし て，(1) 時代といら流れを視野に入れている，(2) かな りの長期間の経過を追っているの 2 点で, 西平（山梨 大）の伝記による研究と類似している.

なお，論文集の訂正は次のようであった。

1. 本田と田中の所属は，それぞれ，(文教大)，(山 梨県立女子短大).

2. $\mathrm{p} 337$ の表 4 の $\mathrm{E}_{2}$ 欄と NA 欄を削除.

3. p 339 の表 3 の下に, 「現在の性を肯定してお り, 家や個人の要因が」を挿入.

（田中政子・本田時雄）

\section{人 格 (401〜408)}

座長 稲 越孝雄・黒田 正典

401 大学新入生の適応過程について（2）

-F.O.C. とその後の大学生活について (1)-

日本大学 (2)嘉 部 和 夫

高久信一
402 大学新入生の適応過程について（3）

-F.O.C. とその後の大学生活について (2)亜細亜大学 (3)成 田

諭

403 教育に対する態度の分析 (2)

一大学生の教育観の因子分析的研究一 文教大学 稲 越 孝 雄 